UC-NRLF

THE

CHINA OR DENNY PHEASANT IN OREGON

\title{
WILLIAM T. SHAW
}

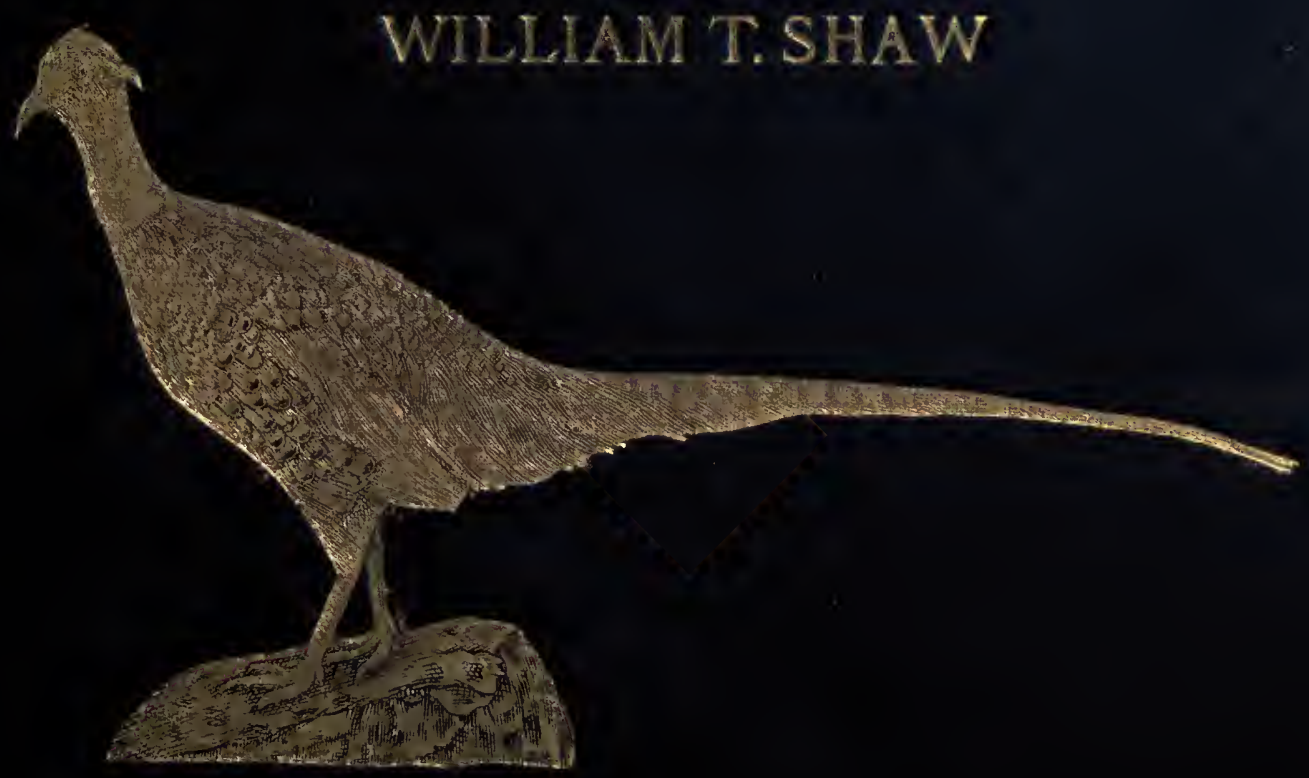




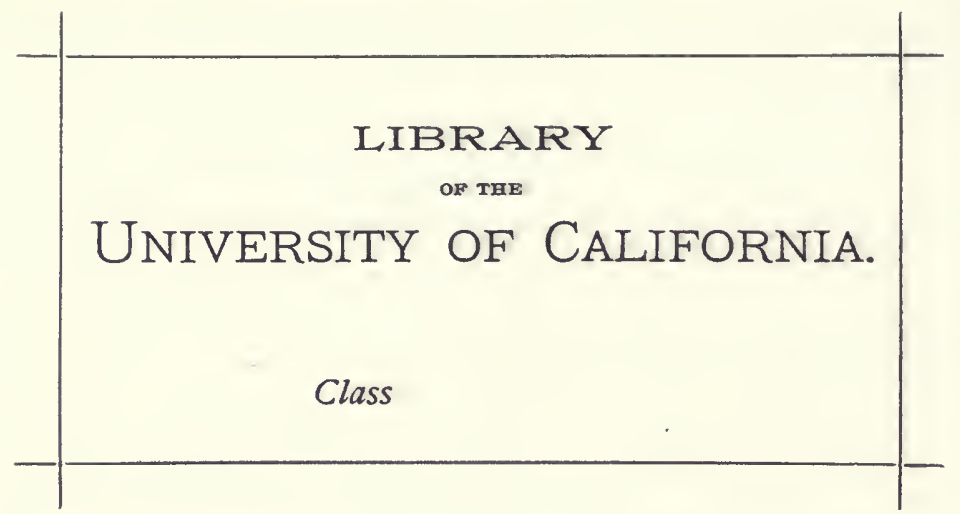


$1,5 w^{t}$ 
THE CHINA OR DENNY PHEASANT IN OREGON 


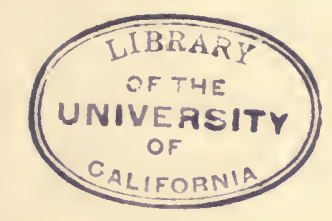




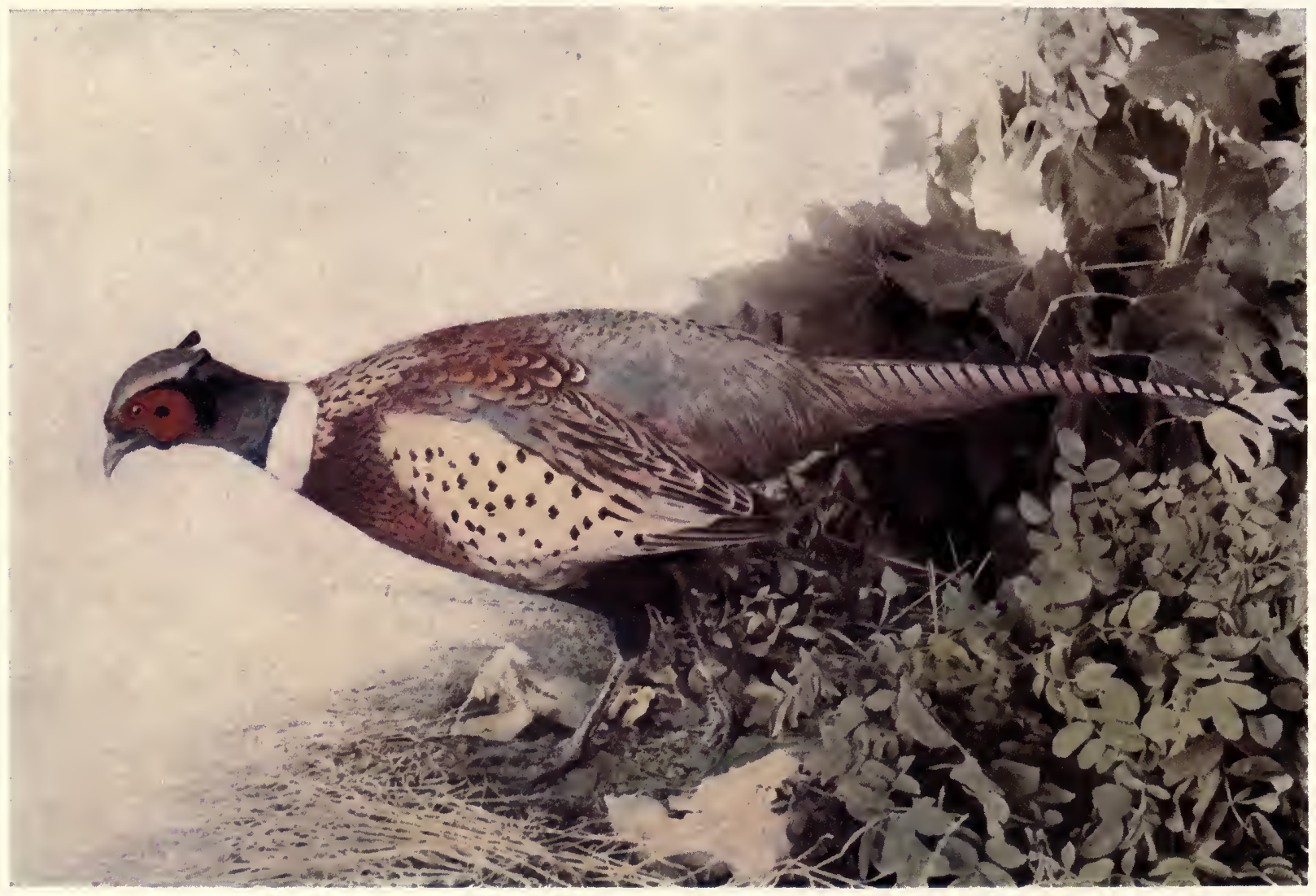




\section{The China or Denny Pheasant in Oregon}

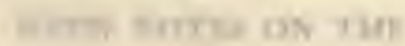

Nathes Gimeune of the Pacitic Northwest

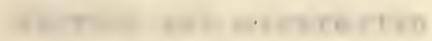 \\ Whot sat hes66ak, fi.Aos., M.S.}

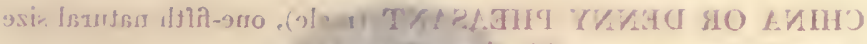

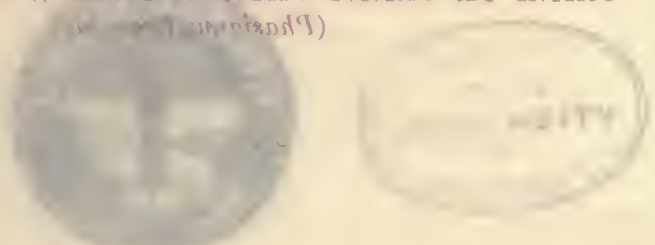

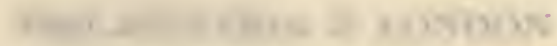

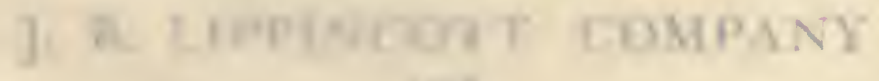
tin 
CHINA OR DENNY PHEASANT (male), one-fifth natural size (Phasianus torquatus) 


\section{The China or Denny Pheasant in Oregon}

WITH NOTES ON THE

Native Grouse of the Pacific Northwest

WRITTEN AND ILLUSTRATED

BY

WILliAM T. SHAW, B.Agr., M.S.

ASSISTANT PROFESSOR OF ZOOLOGY AND CURAT TOR OF THE MUSEUM, STATE COLLEGE OF WASHINGTON

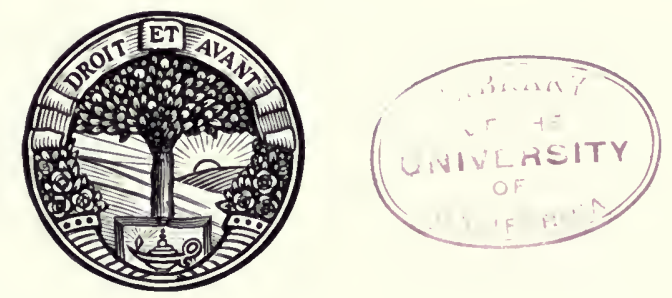

PHILADELPHIA \& LONDON

J. B. LIPPINCOT'T COMPANY

I 908 
Copyright 1906, BY W. T. SHAW

Copyright 1908 , BY W. T. SHAW

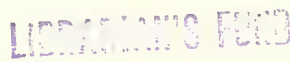

Published Mareh, 1908

Printed by J. B. Lippincott Company

The Washington Square Press, Philadelphia, U. S. A. 
M. J. S-S. 


\section{Acknowledgments}

T THE preparation of the manuscript for this work the writer is indebted to Mrs. 1 O. N. Denny and Mrs. B. O. Scott for many facts relating to the importation of these pheasants. In making the illustrations much valuable assistance was rendered by Mr. B. L. Cunningham. The tinting of the frontispiece was done by Mr. Katso Morita, Japanese artist. Many of the specimens from which the illustrations were made were furnished by Messrs. 'Gene M. Simpson, A. R. Woodcock, H. L. French, F. L. Smith, and Rev. E. F. Green, to whom the writer is grateful.

The writer is also indebted to the works of Dr. Robert Ridgway and Mrs. Florence Merriam Bailey, for information relating to the geographical distribution of the native birds treated in the text.

The illustrations are entirely original, those of the birds being made from specimens mounted and photographed by the writer.

$$
\text { W. 'T. S. }
$$

State College of Washington,

Pullman, February 10, 1908. 


\section{List of Plates}

1 China or Denny Pheasant (Male)

Frontispiere

2 Peterson's Butte

3 China or Denny Pheasant (Female)

4 Nest of China Pheasant

5 Deserted Nest

6 China Pheasant Chicks

7 The Beautiful Willamette

8 Sooty Grouse.

9 Hybrid: China Pheasant-Sooty Grouse

10 Willow Ptarmigan (Alaskan).

11 Sage Grouse .

12 Columbia Sharp-tailed Grouse

13 Oregon Ruffed Grouse

14 Mountain Partridge

15 Valley Par'tridge 


\section{The China or Denny Pheasant in Oregon}

MIDWAY between the states of California and Washington, among the lowest 1 western foot-hills of the Cascades, stands a butte, low and weathered, worn down almost to a cone, yet so bold as to form a landmark toward which wandering Oregonians of the Willamette turn fondly as to scenes of earlier days. Close by to the north flows the graceful Santiam fresh from mountains of fir and alder from which it comes, step by step, over beautiful waterfalls, sparkling cascades, and swirling eddies, murmuring there the subdued song of a high-altitude water-thread, by whose side the weary dust-worn desert traveller, from the sage plains far to the east, drinks and is rested. Below, it flows calmly on across broad prairies to join the beautiful Willamette. Here, by stream and butte, among the hills and grassy slopes, was liberated the China or Denny pheasant, destined to become with remarkable rapidity Oregon's most renowned game-bird.

The story of the introduction of the Chinese pheasant-sometimes called ring-necked-into Oregon is a simple one, yet none the less remarkable in its far-reaching results, for this experiment by the Willamette has undoubtedly given fresh and vigorous impetus to the 
stocking of game in many another state. In 1880 the late Judge O. N. Denny, then Consul-General to Shanghai, after whom the legislature of Oregon has since called the bird the "Denny pheasant," formulated the idea of introducing these beautiful creatures into his home in the United States. In his own words, "The Chinese farmers never shoot the birds nor do anything which tends to frighten them from their fields, holding them friends rather than enemies, doing far more good to their crops than harm by the destruction of insects. They take them with nets and market them alive, but the fact that they were often poor and thin induced me to purchase them by the dozen and feed them until they were fat and fit for my table. On one occasion I had in my inclosure a large number of extraordinarily handsome birds, and while admiring them $\mathrm{I}$ thought, What would I not give to be able to turn the entire lot adrift in Oregon? Then and there the resolve was made."

The first shipment, consisting of seventy birds, reached Olympia on Puget Sound safely and were then put into small ordinary coops to be sent to Portland. 'The coops were left uncovered, and on that short trip they beat themselves so violently against the bars in terror of the strange sights and sounds about them, that but seven or eight reached their destination alive; and they were so bruised that they soon died. With some the story would have ended here, yet apparent failure, accompanied as it was by no light 
expense, only gave the participants a deeper assurance of its ultimate success, and this initial trial was to form the foundation for future efforts. So it followed that a year later Judge Denny made a second trial, this time with success. The utmost care was taken. The services of a tramp steamer coming to Oregon were enlisted, a scow-load of sand was brought alongside and deposited between decks, several small boat-loads of various kinds of food, green stuff and grain, together with sundry large bags of charcoal were placed on board for their use, and the captain and sailors were paid well to attend to their wants. Poles of bamboo caged off a neat airy room some twenty feet square, and here in semi liberty thirty birds were turned, and here they stretched their wings and fluttered and scratched in the sand and ate of the food provided for them. Talk of the hardships of an ocean voyage! Indeed these birds actually grew fat. Only four perished on the way and the remainder after reaching Portland were placed in the large cage which had been made under Judge Denny's supervision and shipped with the birds, and immediately turned over to a brother, Mr. John Denny, who had come to Portland to receive them. He took them to his large ranch in Linn County in the Willamette Valley, and here at the foot of Peterson's Butte the travellers were liberated. Grain was scattered about freely; a little band of friends and neighbors took the cage up the mountain side, and after opening the door, hid themselves and waited for the birds to come forth. They 
found their way out slowly, purring about and stretching themselves and keeping near their cage, seeming to feel that it was home. For a long time, indeed all through the following winter, they did not go far away, but came about the farms, sometimes coming to feed with the chickens. Gradually, however, their wild nature triumphed, and as they became acclimatized and used to the bearings of the new country in which they found themselves they strayed off farther and farther. Soon after an act of protection was passed by the legislature for a period of five years. At the end of that time the act was renewed for another five years, and by that time the birds had become so successfully acclimatized as to withstand the most vigorous annual onslaughts. Thus encouraged, and disregarding the heavy expense which these undertakings incurred, Judge Denny resolved upon a third. This time, about two years later, his attention was turned toward a shipment of pheasants and partridges, ninety birds in all, in which the ring-necked was not.a predominating factor. The ones now sent were largely silver and copper pheasants, the latter, beautiful long-tailed birds, with plumage of burnished copper color which reflected brilliantly from them as they flew through the gleaming sun-rays. The shipment also contained a little Chefoo partridge, petite and unique in its spotted plumage. These also survived transportation finely, and were turned over to a club whose members thus assumed the responsibility of bearing further expense. The birds were transferred to a 
suitable island in the Columbia River and there turned loose in charge of a rancher. Unfortunately, however, through a series of unforeseen circumstances the organization lost control and in the course of time the birds became scattered. Regarding the fate of the partridge and copper pheasant, little is known. It is said that the latter, being strong of wing, have subsequently escaped to the mainland and become lost to record. Many flocks of silver pheasants now west of the Cascades trace their ancestry to this island in the Columbia.* The success of the second shipment of birds, which were taken charge of by Judge Denny's brother, Mr. John Denny, is now a matter of history, for it is from these, the ring-necks, that the Pacific Northwest is stocked. We remain indebted to the forethought, energy, and determination of those who, in the face of obstacles and discouragements, brought it to completion. In the light of these facts it seems unfortunate that the name "Denny pheasant" cannot be more universally used. For this account of the introduction of the pheasant into Oregon the writer is indebted to Mrs. O. N. Denny, to whose efforts, together with those of her late husband, the success of the enterprise is largely due.

There were splendid native birds in the state before the pheasant, but for numerous reasons many of them are fast disappearing. Nowhere in all America are found more species of magnificent native grouse than in the West. Passing the Rocky Mountains

* Protection Island, Washington. 
one meets the Dusky, Richardson, Franklin, and the Sooty; all timber birds of unusual size, the male dusky being over twenty inches in length, remarkable dimensions for a bird so stocky as the grouse. Several species of Ruffed grouse appear throughout the forest tracts, while high on the mountain sides by the rims of perpetual snow lives the beautiful White-tailed Ptarmigan. On the plains the Sage and Sharp-tailed still live, largely unmolested. For some of these the story of extermination may soon be written. Their very nature is against them. One at least, the sooty, is even now having its diminishing ranks rapidly filled by the imported bird from the Orient.

Pioneers of the early days tell of the strange henlike birds, met with on their journey across mountain and plain. "Fool-hens," they called them; birds without apparent fear of man, that stood calmly eyeing him from the path at his feet, or craning their necks from the lower branches of a near-by tree, often to be actually clubbed to death, for their flesh was good to the sturdy traveller. Remote mountains hold them yet. Fool-hens they were, fool-hens they are still, to their own destruction and possible extermination.

Of these, the sooty, or " hooter," or "blue" grouse, deserves more than passing notice; for it, with the Oregon ruffed grouse or "drummer," now popularly spoken of as "natives" in distinguishing them from the exotic bird, together with the Mountain Partridge or" "quail," constituted the original upland game birds of the Willamette Valley, and it 
seems to be the only one of these to be losing its ground. The reason is apparent. The partridge is small, prolific, very swift and active, and owing to its size is less sought by sportsmen. The ruffed grouse too, though larger, is very alert, and is further possessed with remarkable protective coloration. He seems actually to thrive in partially settled land where shrubs bearing wild fruits abound. But with the sooty grouse it is different. He is larger and somewhat slow of flight, and in early days at least, before hard experience had taught him the ways of man, was a fool-hen too. Men, still young today, tell you that in their boyhood they have actually killed the fledglings of these birds with sticks as they fed about shocks of wheat. Others tell of shooting whole flocks, picking them off, one by one, from a fence or tree-branch, down to the last bird. They were not meant to withstand civilized progression. These grouse spend the late summer in the wheat stubble skirting the timber of the foot-hills, but as winter approaches, take to the mountains. Here, high on the great, flat, tree-like branches of the giant firs, they live throughout the winter, feeding upon the small needles, and, it is said, rarely if ever coming to the ground. But the fir too, and with it their winter food supply, is passing before the ax and forest fire. Later, from this same position, they drone their love-note of spring, uttering, at intervals throughout the dreamy, breathless days, a stifled nazal hooting suggestive of the great owls. And here again the settler's ear is attracted, and his rifle trained upon 
them, standing fearlessly outlined against the sky, until at last a bullet more true than its predecessor, and the bird is cut down.

Some even say that the China pheasant is aiding in the work of extermination, but it is more probable that careful scientific observation will show the real trouble to rest largely with the grouse, it being unable to adapt itself to the new conditions accompanying the settlement of the country.

In a curious way the territories inhabited by the sooty grouse and China pheasant seem to overlap in such a manner as to leave them largely independent of one another, yet resulting occasionally in the appearance of hybrids. Of these more will be said later: As stated before, the grouse is largely a bird of the timber, appearing in the fields in autumn, wintering and breeding in the mountains and foot-hills. The pheasant is primarily a bird of the fields, showing only a slight tendency to seek the shelter of the foot-hills during winter.

To know the pheasant well, one must live with him throughout the year. He is a bird of moods, influenced by shifting conditions and passing seasons, of which there are for him, in reality, but two,--the open and close. Within a few days after the law says no more shooting, he becomes bold and fearless, even to the extent of sharing the food of the barn-yard fowls in winter, though always reserved and suspicious. In the brush 
of the lowlands, or from the open meadow, comes his two-syllabled call in the stillness of the evening twilight. From his roost among the grass or sedge tussocks, or the great moss-covered branches of an oak, he springs away into the gloom with a startled cry. Throughout the long dry summer the young are reared by the female, until the days of autumn come; the male meanwhile frequently greeting you by the roadside with a glance of curiosity mingled with reserve, standing a moment, erect, in all his brightness of coloration, ducking an instant later to steal silently away among the grass.

But his quiet soon ends. In the gray dawn of the first day of the open season, his peaceful fields soon become a firing-line. In singles, doubles, and fours, reports echo from hillside and lowland, and the bewildered bird flees, he knows not where, in escaping the hunter, even seeking the friendly orchards of corporate towns where his pursuers may not follow.

His panic is not for long, and here it is that sympathy and admiration go out to the bird in this heroic effort to live. Here it is that the traits of stealth, cunning, and endurance, which are very life to him, are most strongly shown. The brief space following the first day of the open season is usually one of comparative quiet, allowing him to return once more to old haunts. The long months of peace have placed him momentarily off his guard, but like the routed yet determined and undefeated soldier he falls back on his 
reserve, calling up the best there is in him. No longer he stands in the open. The hunter with his dog enters one side of a field, he slips quietly out the other. The setter, threading the stubble in hot scent, points; but before his master has taken a dozen steps forward, the bird slips into a dead furrow and runs with the swiftness and stealth of a cat, while the dog is momentarily baffled. On and on they go, and when at last he comes to point, and holds, the hunter is to see a remarkable sight. Suddenly there arches into air, with spasmodic cry, and wonderful swiftness and power, the most brilliant and thrilling object in all the field of upland sport. For the fraction of a moment he poises in the air; only to get his bearings, then away!-gradually rising for a hundred yards or more, with intermittent cry and vibrating ribbon-like tail, to drop again into a sinking, soaring flight, far over the meadows. Strong men follow this elusive game, and when the law's limit for the day (10 birds) has been reached, both man and dog are ready to rest.

His home life is peaceful, as quiet as are the colors of his mate.

One late-spring morning a boy went fishing up one of the little streams beside our town. In quest of bait he strolled into a near-by pasture for "hoppers." A few yards inland he suddenly stopped short and whistled a low, long-drawn note.

“An old China's nest," he breathed, and after standing a moment shrugging his shoulders in childish admiration, tiptoed away. That night he told me of his find. 
"Yes sir, a China's nest with a dozen eggs!"

"You go over the trestle and drop down into the pasture, then follow an open furrow southwest about ten yards until a pole and balm tree on your right come in line, then over at the foot of a little rose-bush about five steps away you'll find the nest."

Next morning I went "over the trestle," and there in a slight dusty hollow, probably the footprint of some heavy animal, made when the ground was soft, surrounded by a little dead grass, and shaded by a mere sprig of briar, scarcely more than a foot high, lay a nest full of beautiful brownish-drab eggs. One more had been deposited, and today there were thirteen, but not a bird in sight. Two days later I returned to find the same conditions, and so with occasional visits during subsequent days. Only twice did I get a glimpse of the buffy-brownish mother as she slipped quietly from the nest into the surrounding grass, and then only towards the end of the period of incubation. But on the twenty-second day after the last egg had been deposited, several little chips appeared on the hitherto glassy shells and many far-away voices peeped faintly from their prisons. The following day revealed thirteen empty shells, but not a bird in sight; they had been led to the brush by the anxious mother.

Summer passed with only an occasional glimpse of the little brood, now in the bushes, again sunning or dusting in the powdery wagon-trail, but not until early autumn did the 
young males begin to discard the quiet dress of the mother for their brilliant adult plumage.

The fact before referred to, that hybrids are appearing among the grouse and pheasants, is creating a good deal of popular comment and scientific interest. Already several of these crosses between the China pheasant and sooty grouse have appeared, bred in the wild, and it is rather unauthentically reported that ruffed grouse hybrids have also been seen in the Valley. There are in Corvallis at the present time, strange, ungainly birds, resulting from the cross between pheasants and domestic fowls.

The sooty grouse-pheasant hybrids are beautiful birds, but rather inert and spiritless, showing, in an interesting though an inconstant way, markings of both species. Two of these birds, captured in the woods while still chicks, and reared in captivity, led peaceful, uneventful lives, growing to a magnificent size, but showing no inclination to breed.

Of late years there has been shown among the residents of Western Oregon a desire to domesticate China pheasants, but on account of the apparently untamable nature of the birds, the results are often discouraging, though by exercising skill and knowledge together with the proper amount of patience and perseverance, very gratifying results are obtained by some, and their rearing in domestication has led to an industry of considerable interest and importance.

In domestication the eggs of the pheasant are usually hatched under bantam hens, 
with which the chicks run for some time subsequently. As might be expected, the last few days before hatching are full of interest and anticipation for the pheasant-breeder. At first tiny chips appear. These enlarge somewhat and the chick seems to turn. With the little embryonic elevation on the beak it again cracks the shell, turns still farther, and cracks again until a line has been broken two thirds of the way around. Then by renewed effort on the part of the chick, the lid-like top of the shell is forced off. It frequently happens that the shell membrane remains unbroken under the uninjured part, thus forming a hinge for the lid.

The young pheasants are at first fed on a meal consisting of hard-boiled egg and rolled oats, and later with fresh-ground meat crumbled with shorts and cracked wheat. Young pheasants are very fond of both adult flies and their larvæ, and in order that these insects may be secured for them it is customary to place a little fresh meat in the yards to attract the flies, and it is not an uncommon sight to see a little circle of half-fledged chicks sitting in the sun about a piece of meat waiting for the luckless fly to alight upon a grassblade beside them.

One breeder, the most successful of those operating on a large scale, after carefully studying and experimenting for ten years, has succeeded in bringing to maturity only a relatively small percentage of those hatched. Freedom seems to be their one great desire, 
so persistently shown as they pace restlessly back and forth behind their prison netting. We are doubly impressed with this fact as we pass to adjoining runs containing golden and silver pheasants in perfect content.

This briefly is the story of the introduction of the China pheasant into Oregon, a short history of an experiment so marked with success as to cause national comment. 


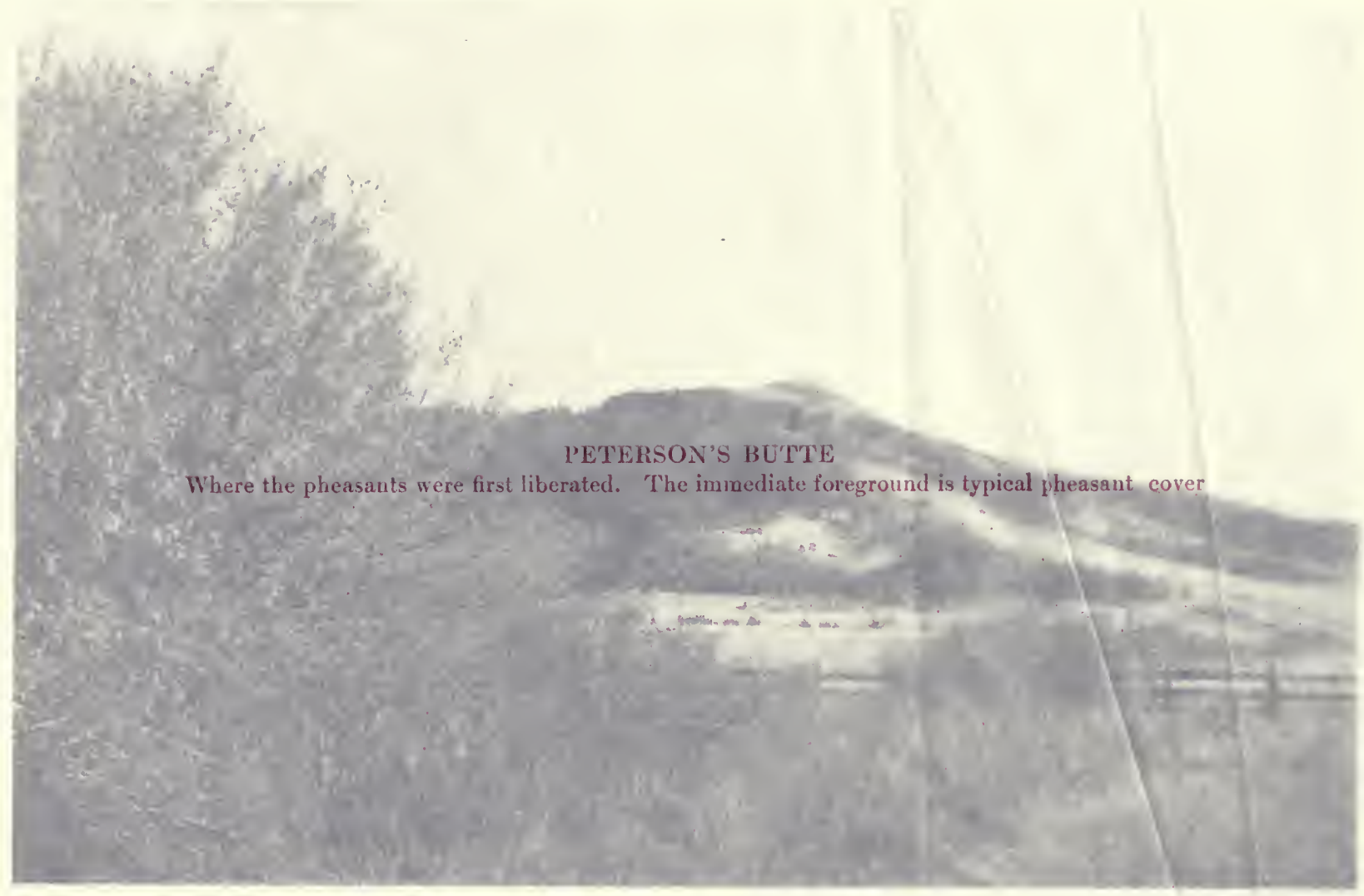




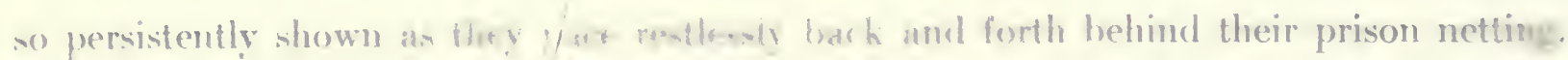

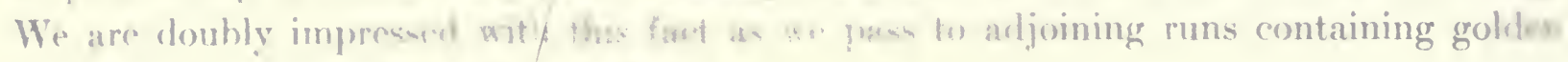

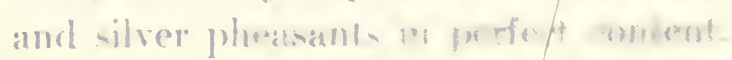

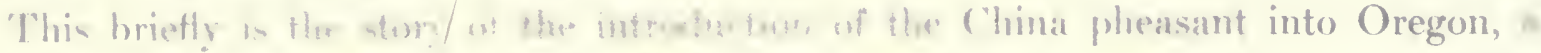

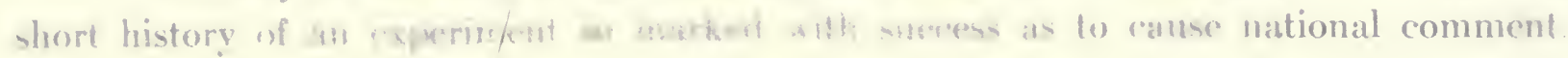




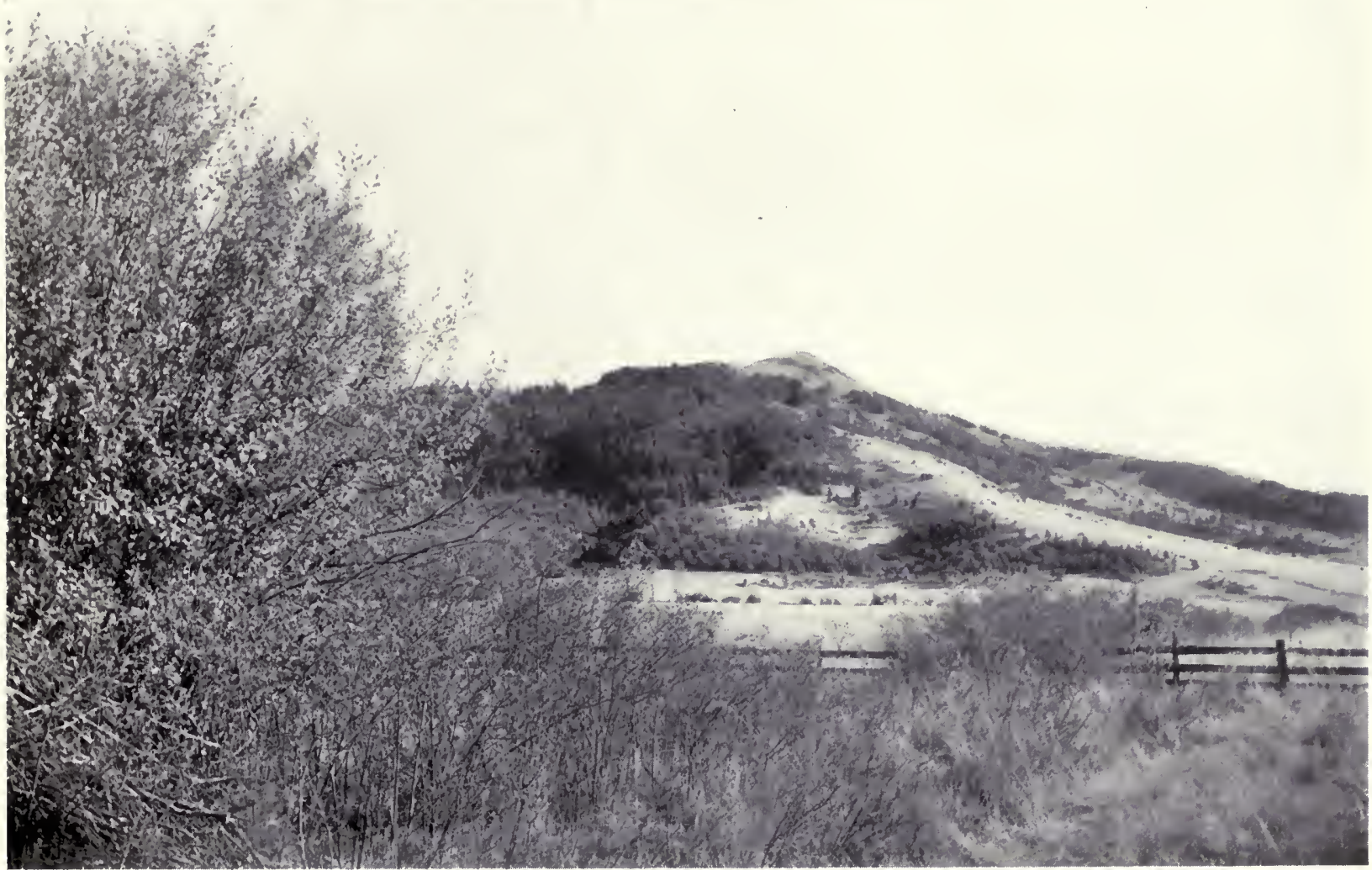




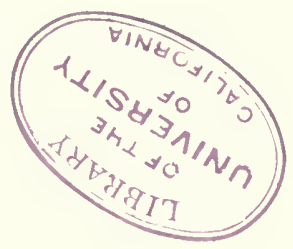




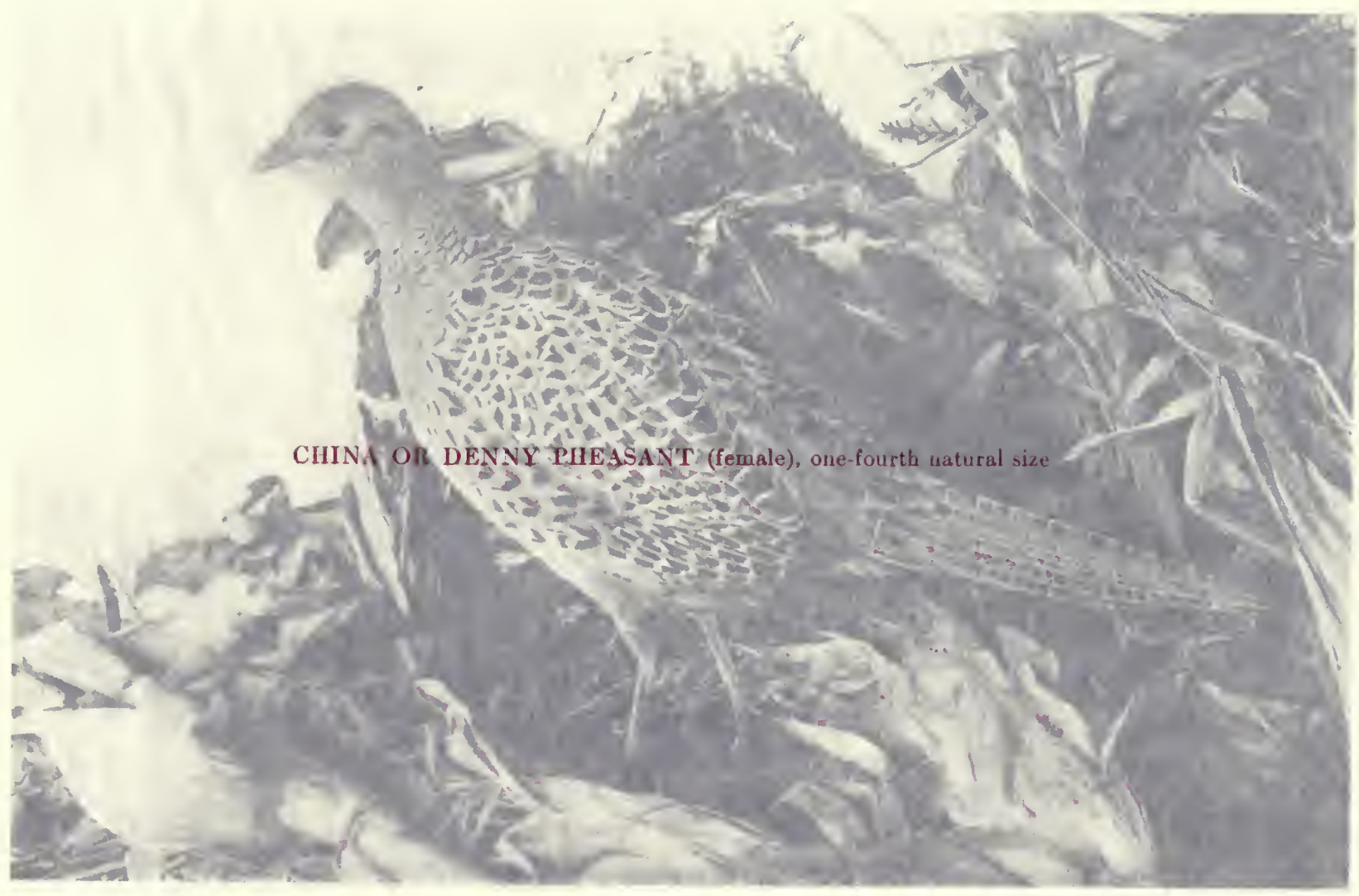




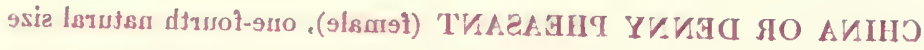




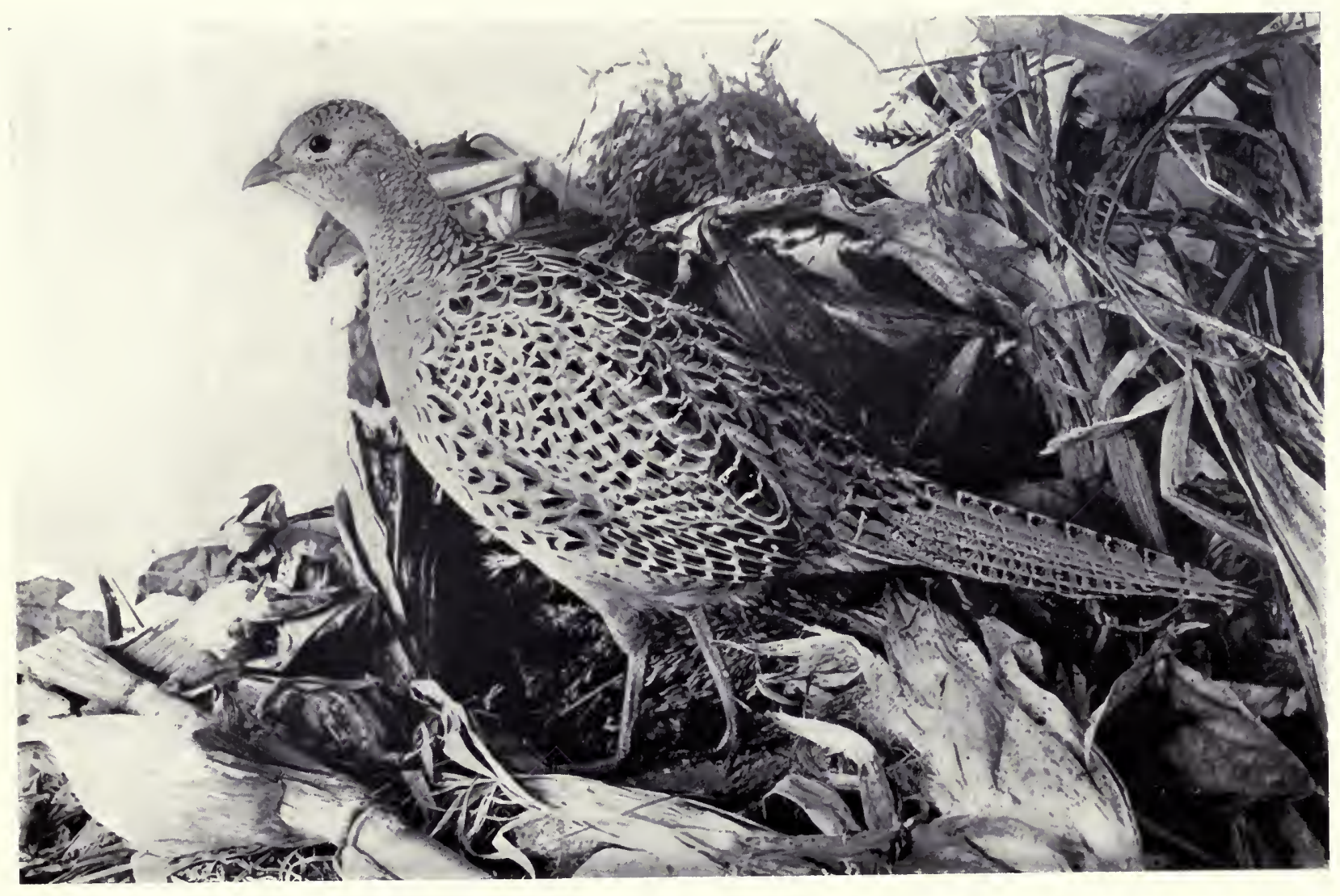




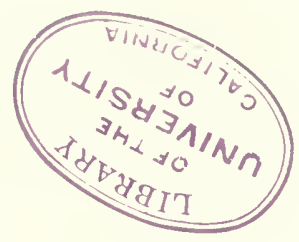




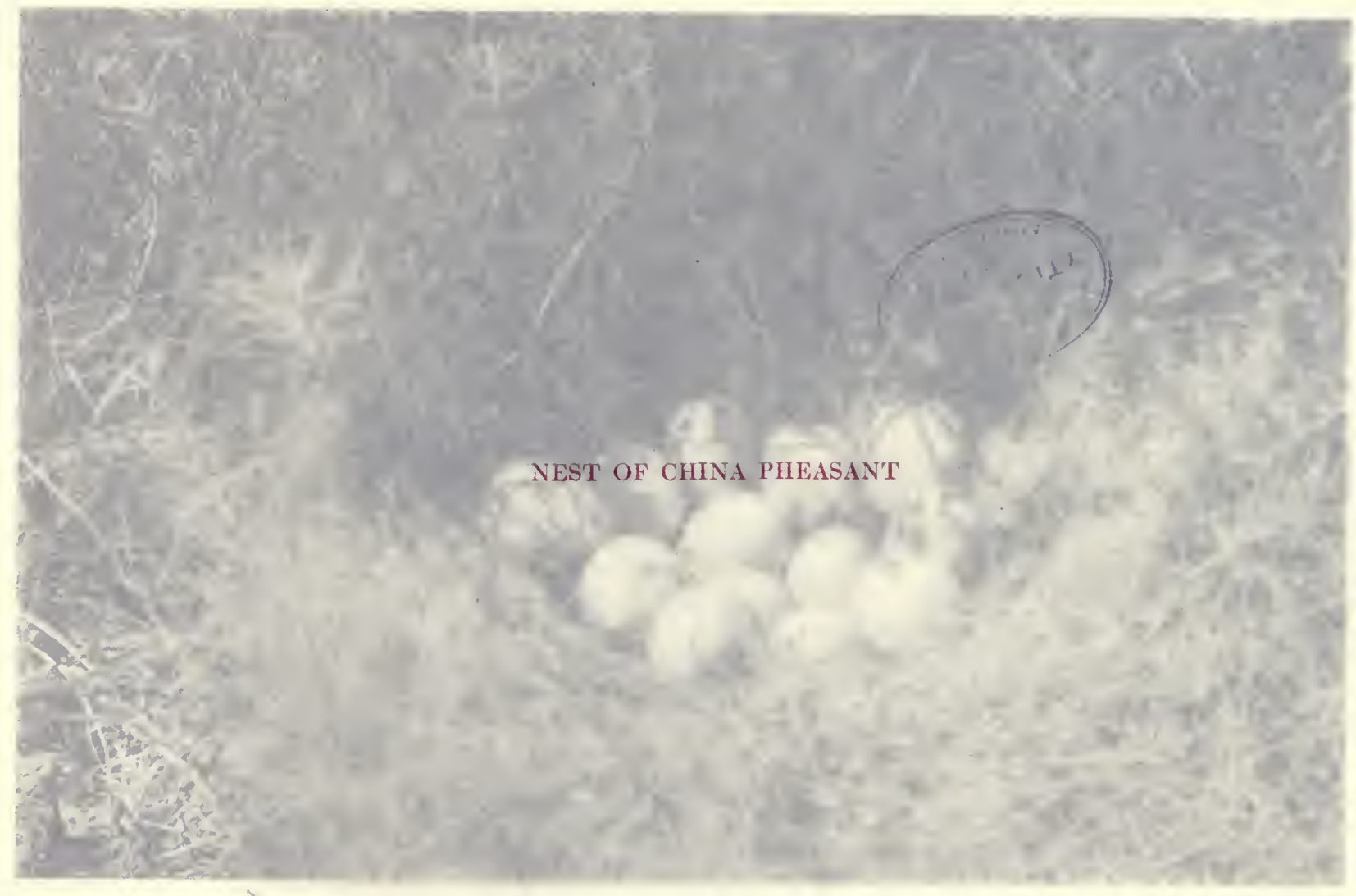




$$
\text { s- }
$$




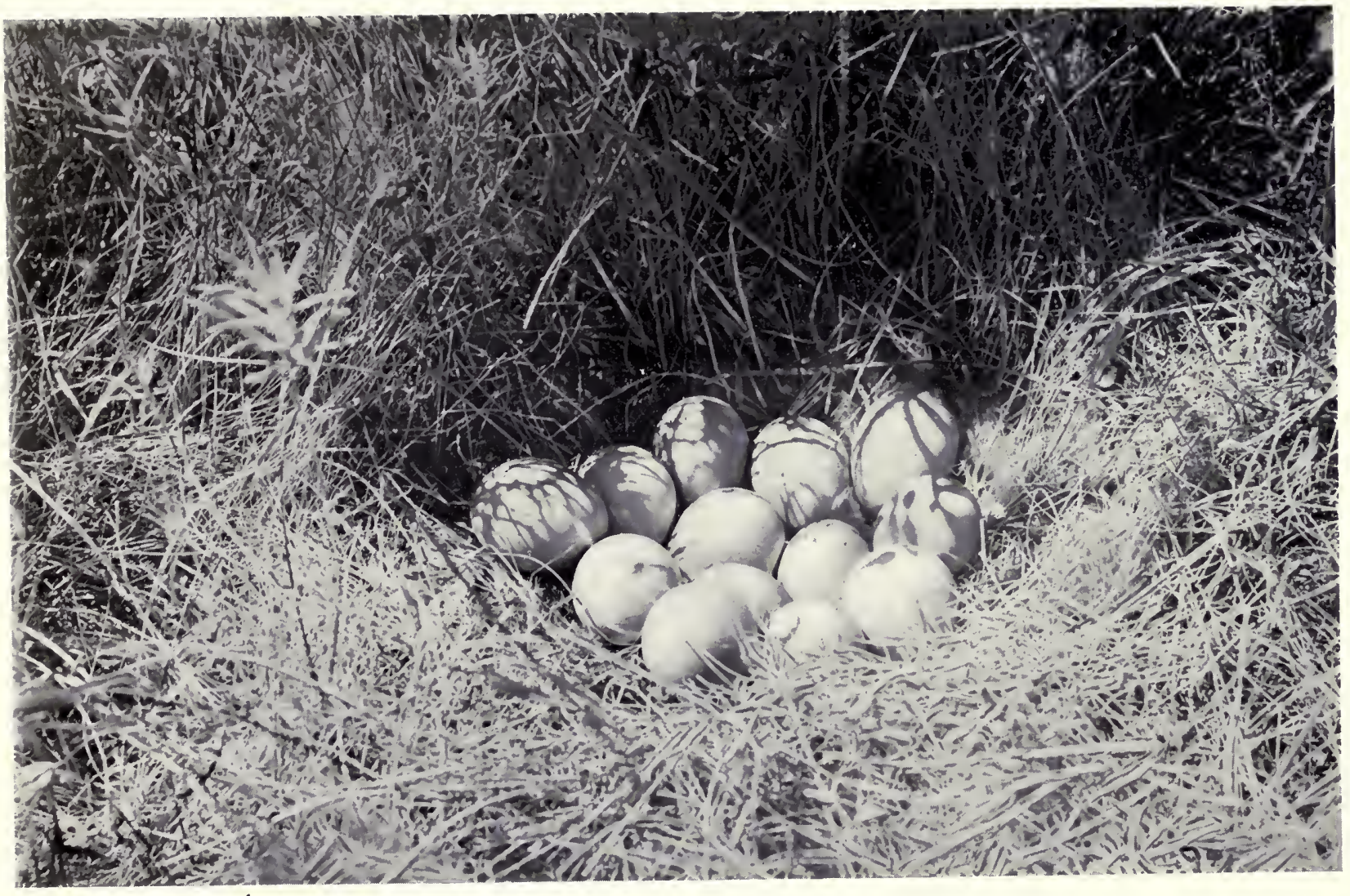




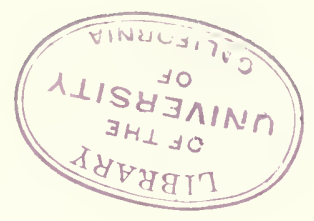




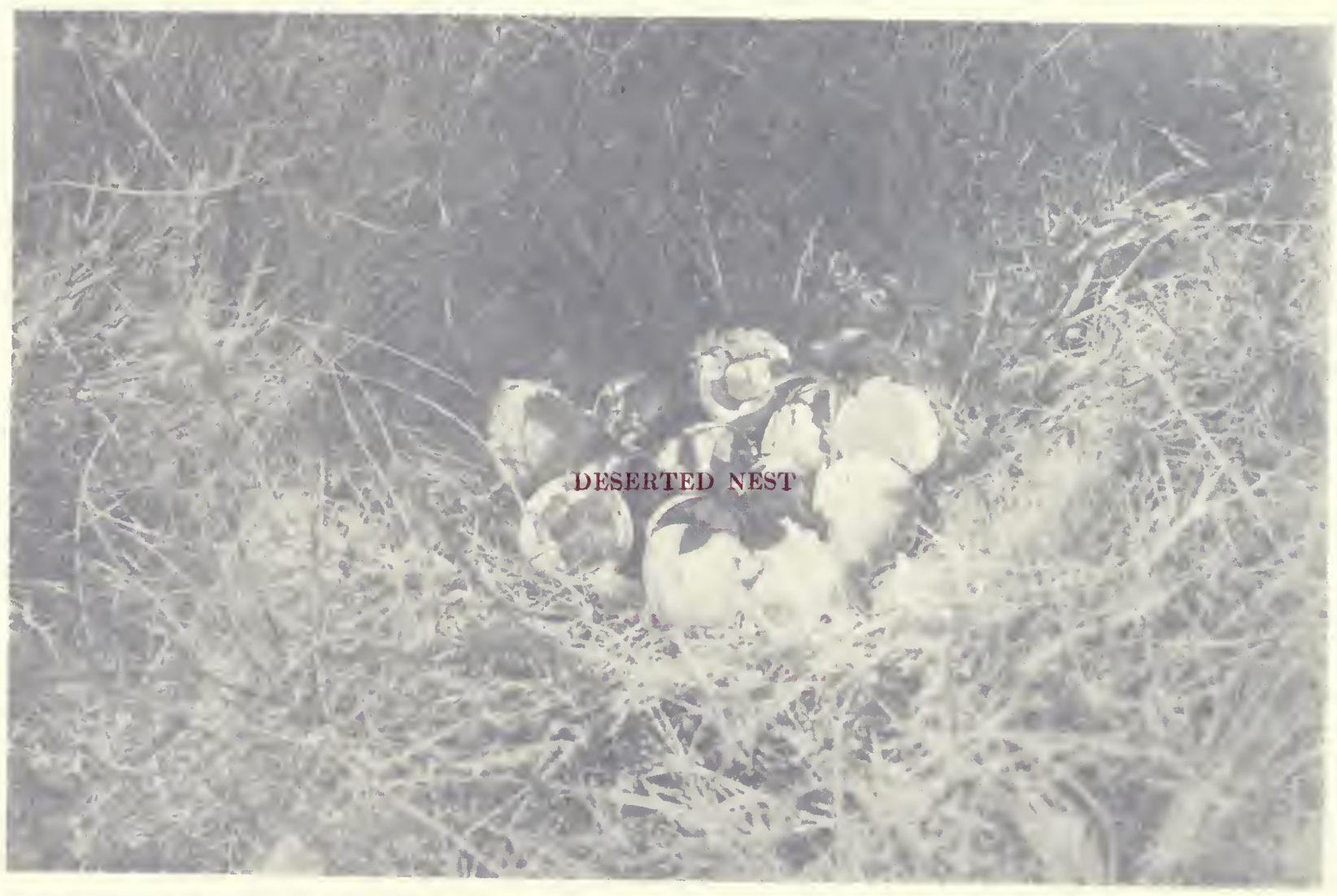




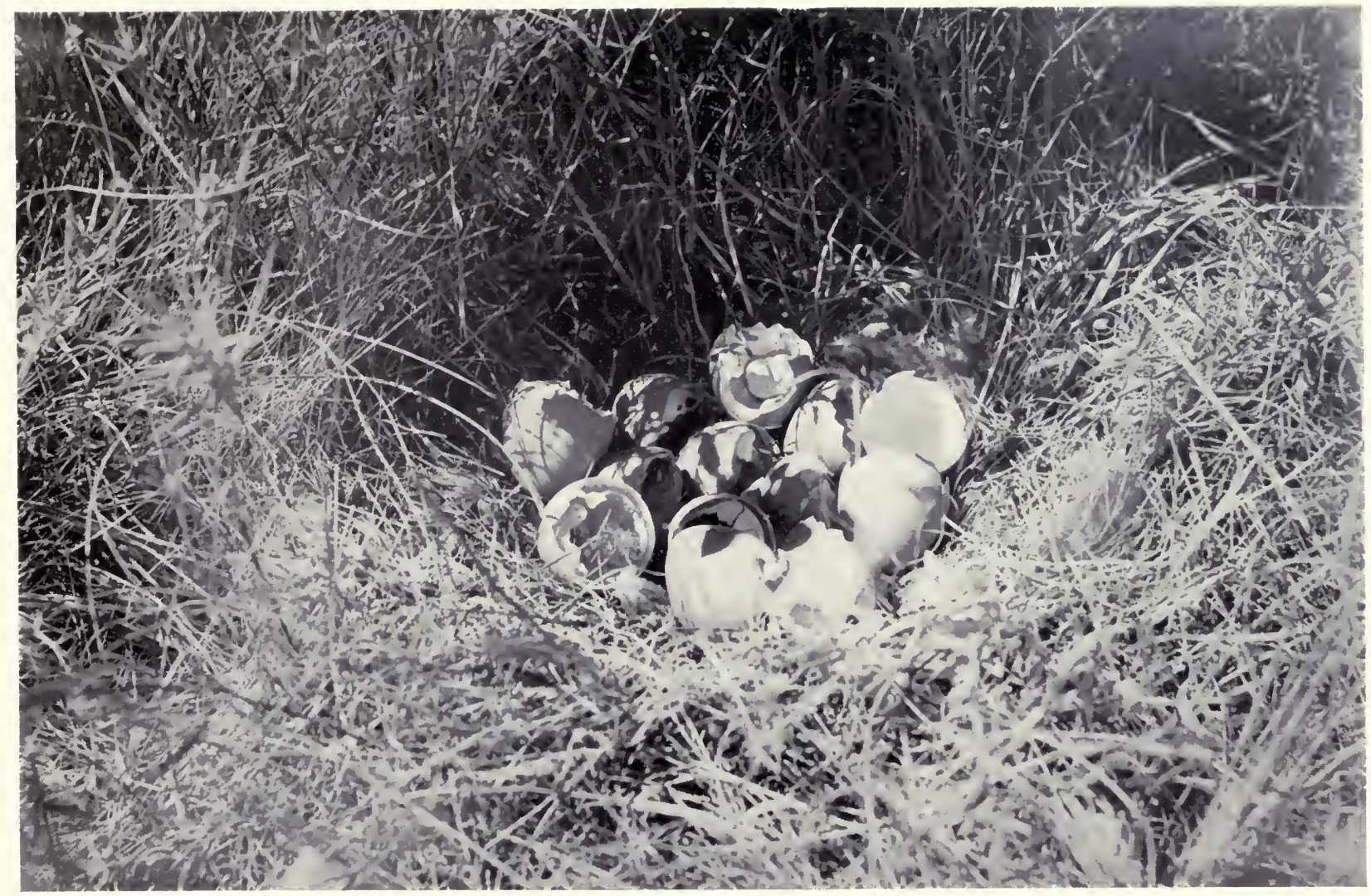




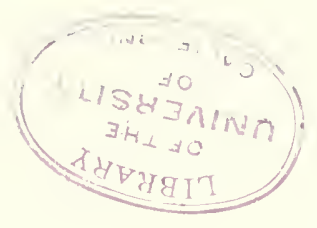




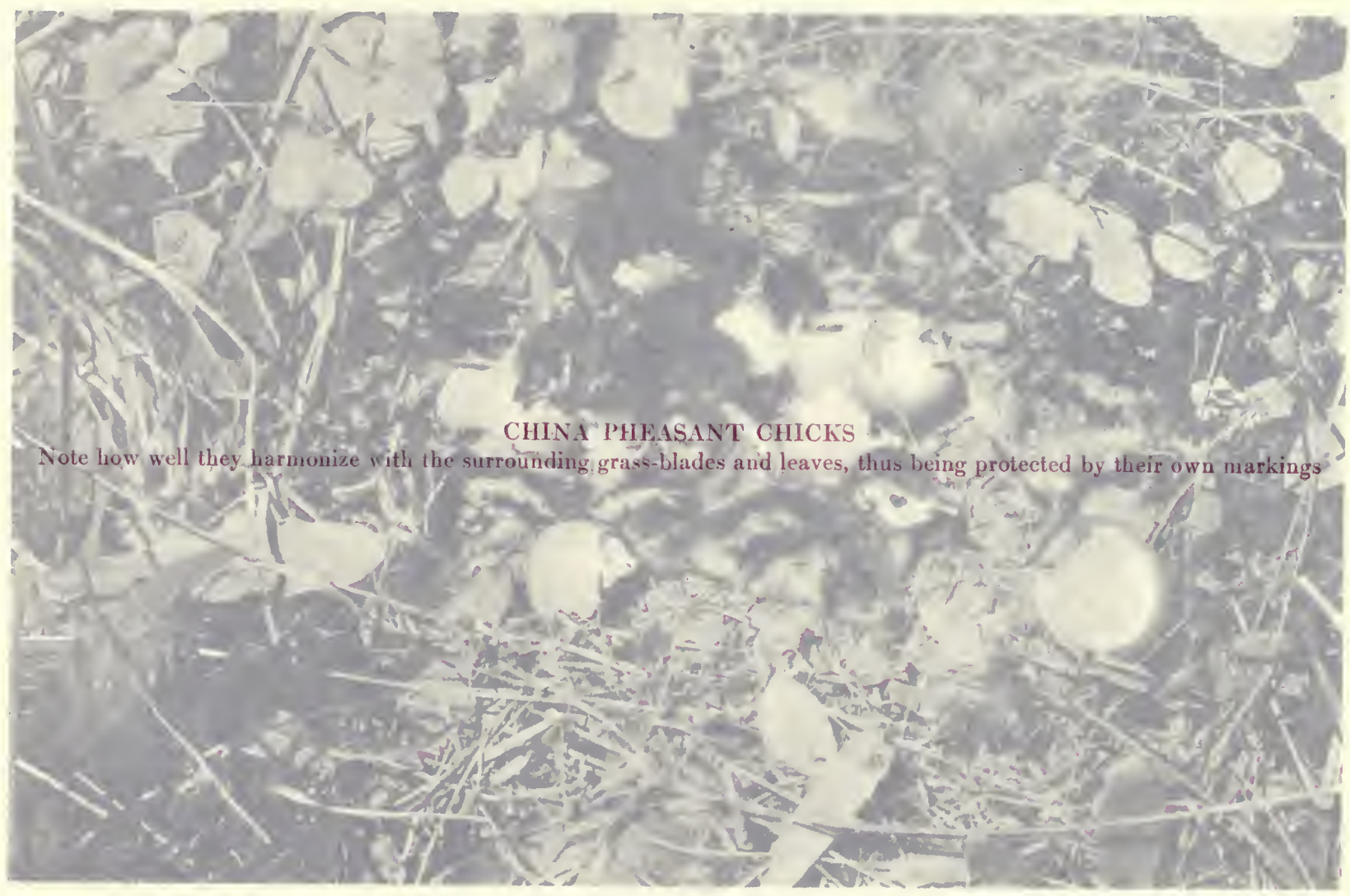




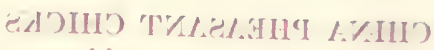

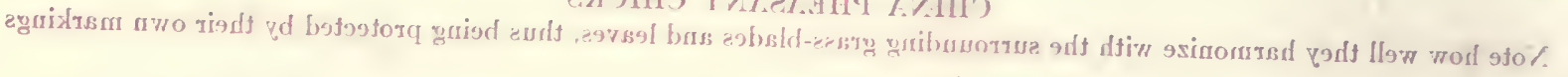




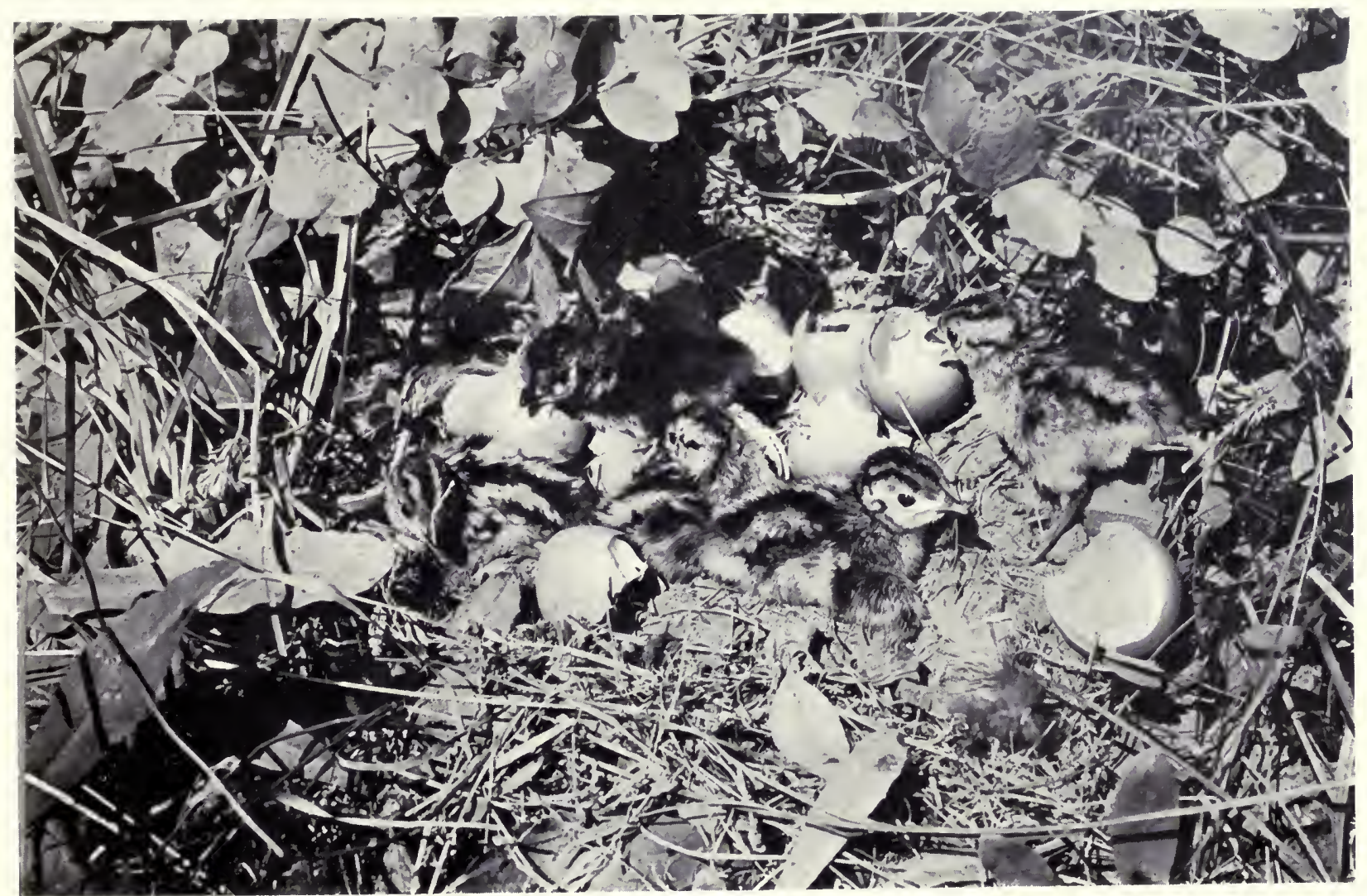




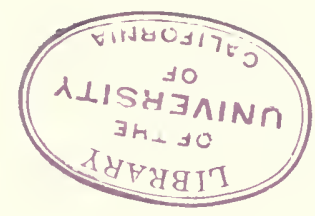




$$
-
$$




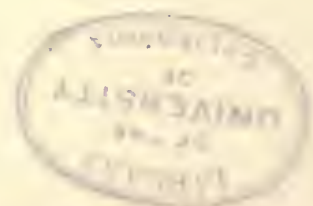

gomsfaib gdt ai эgns 


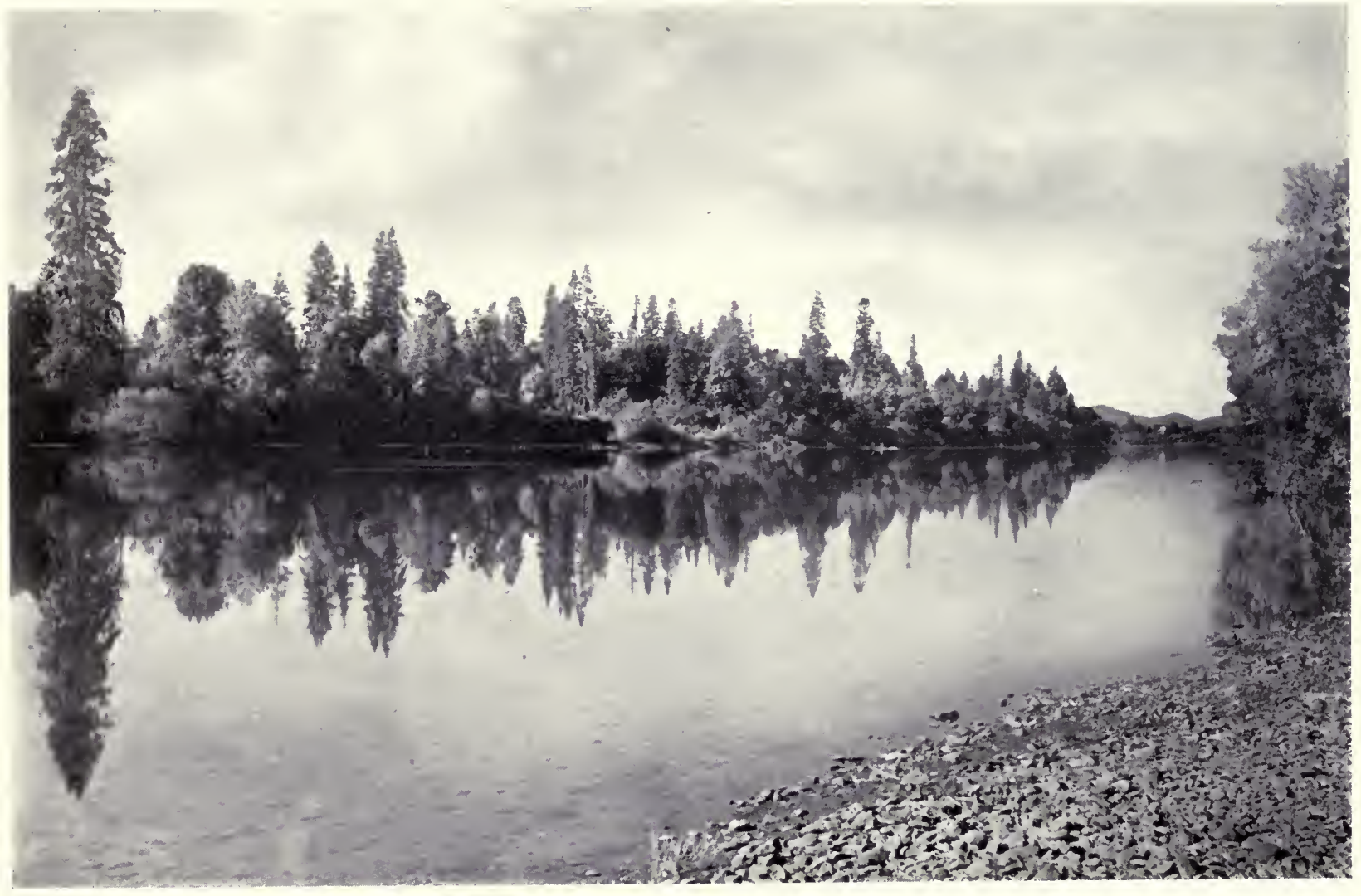




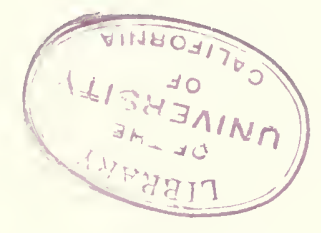




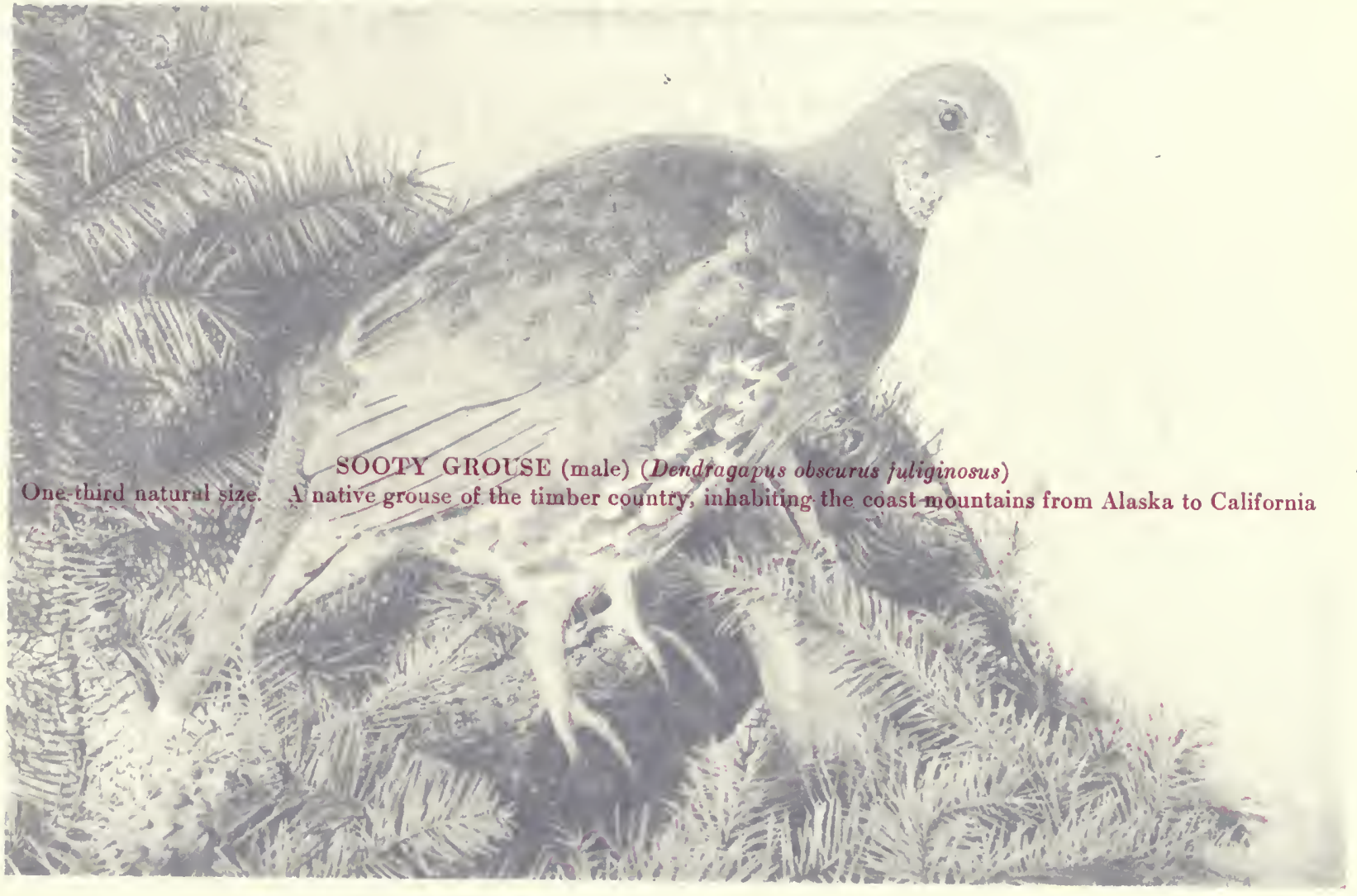




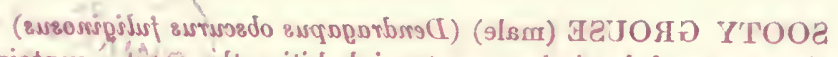

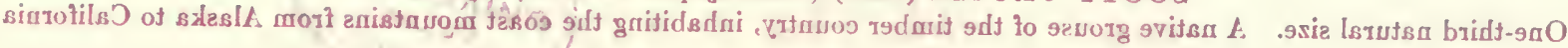

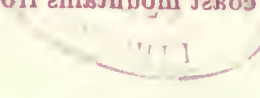




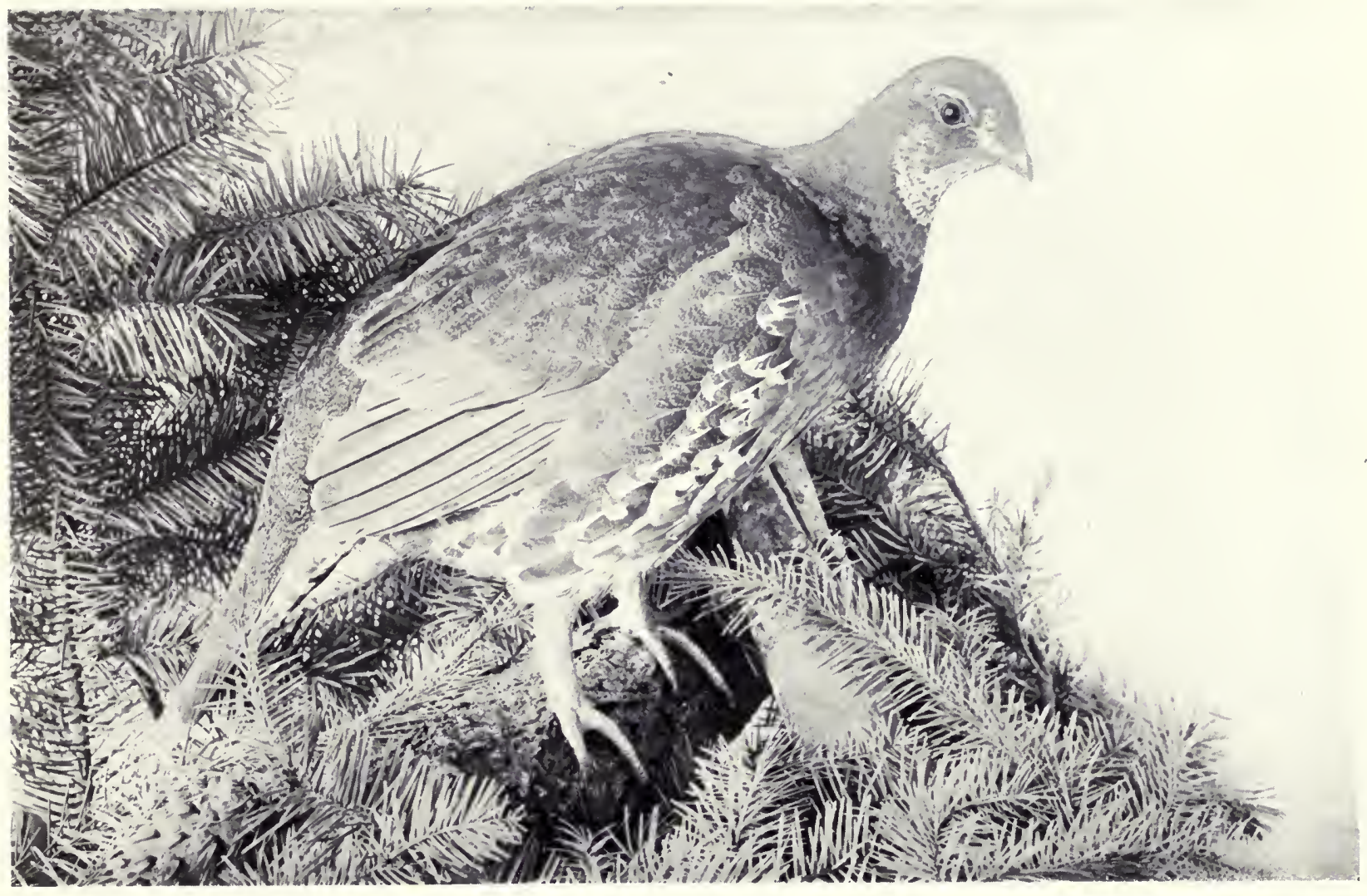




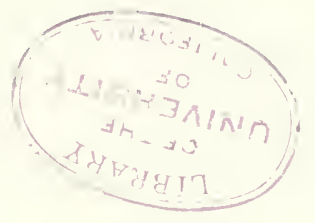




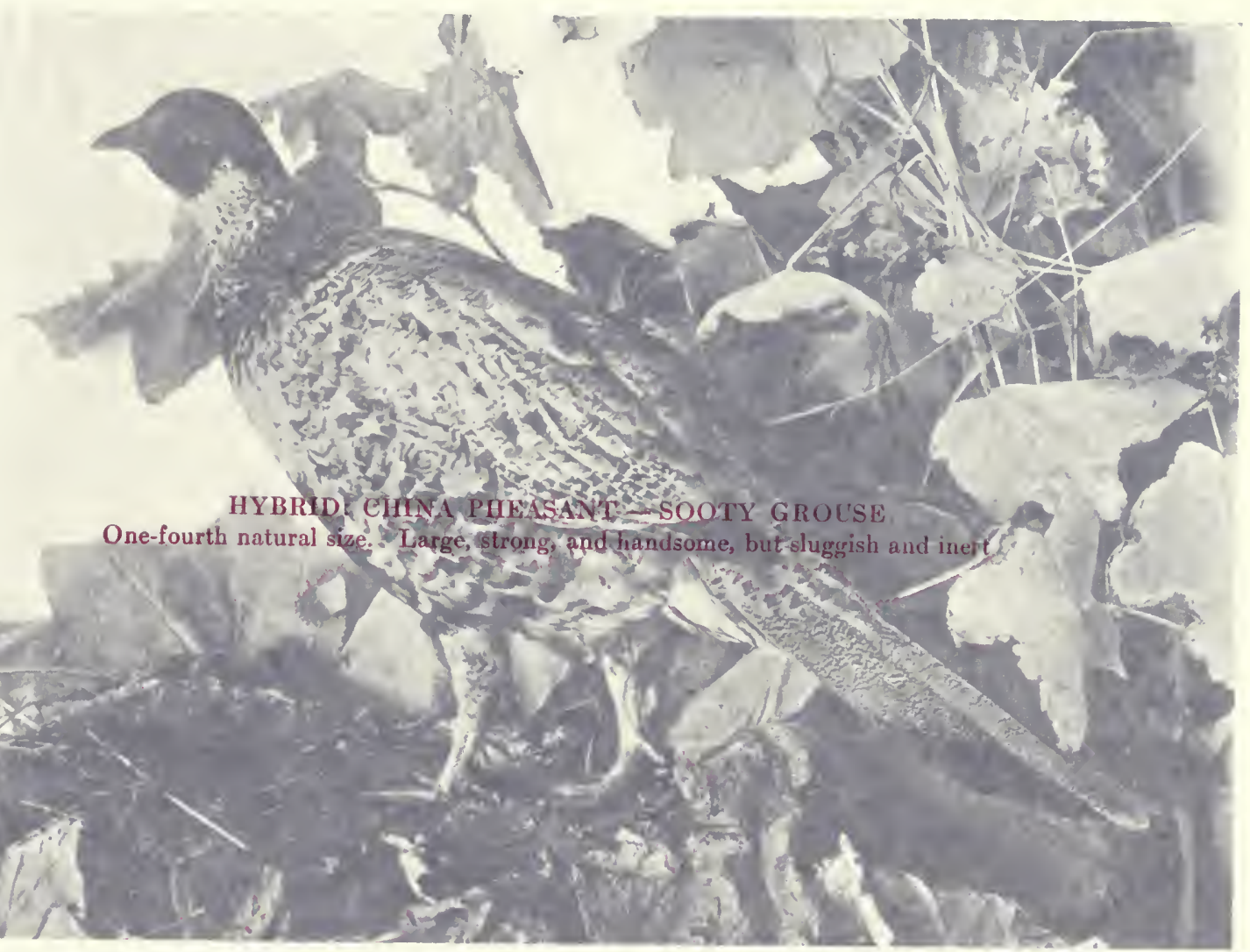


ЯаЈОЯD ҮТООД - ТИАДАНН АИІНО : ФІЯЯYН

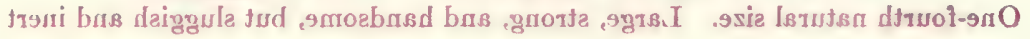




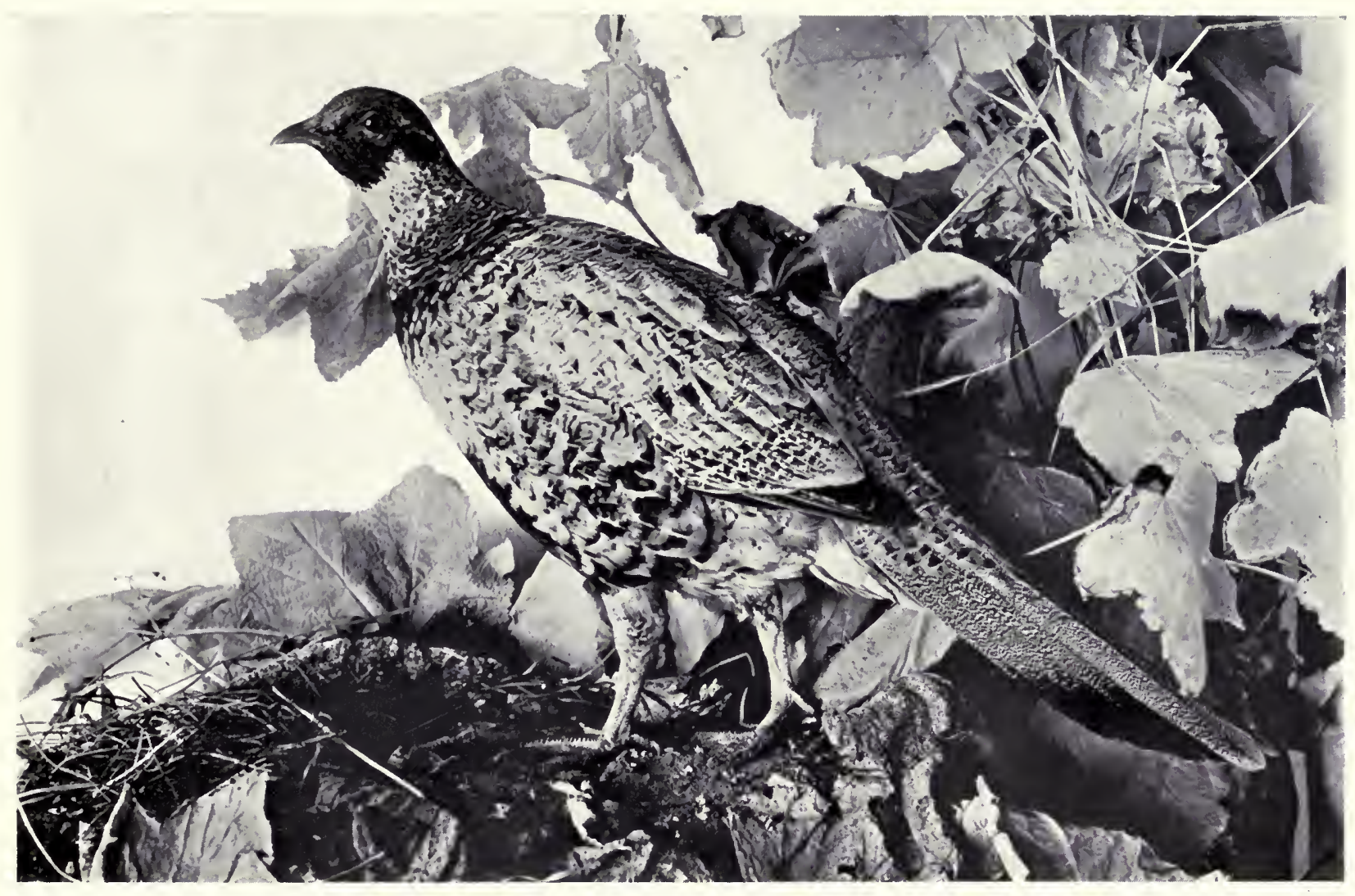




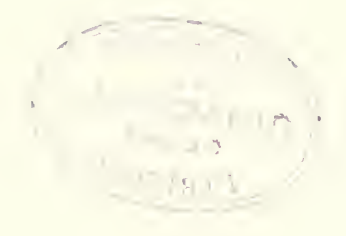




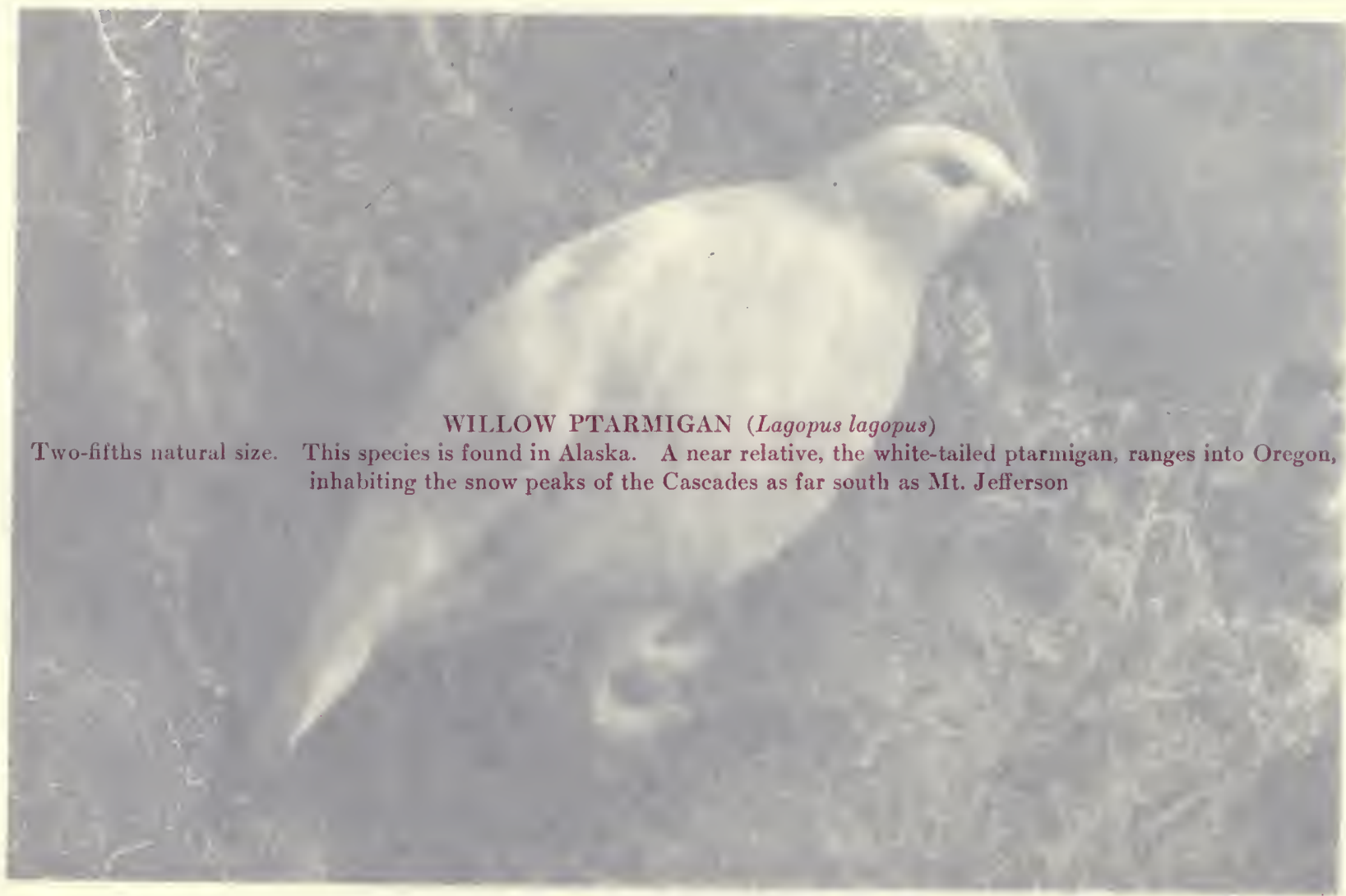




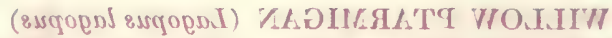

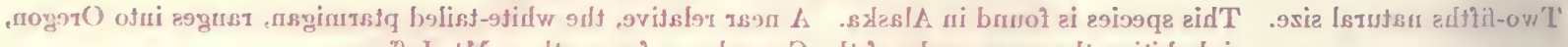

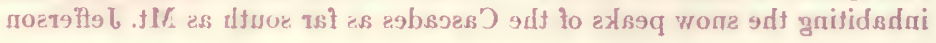




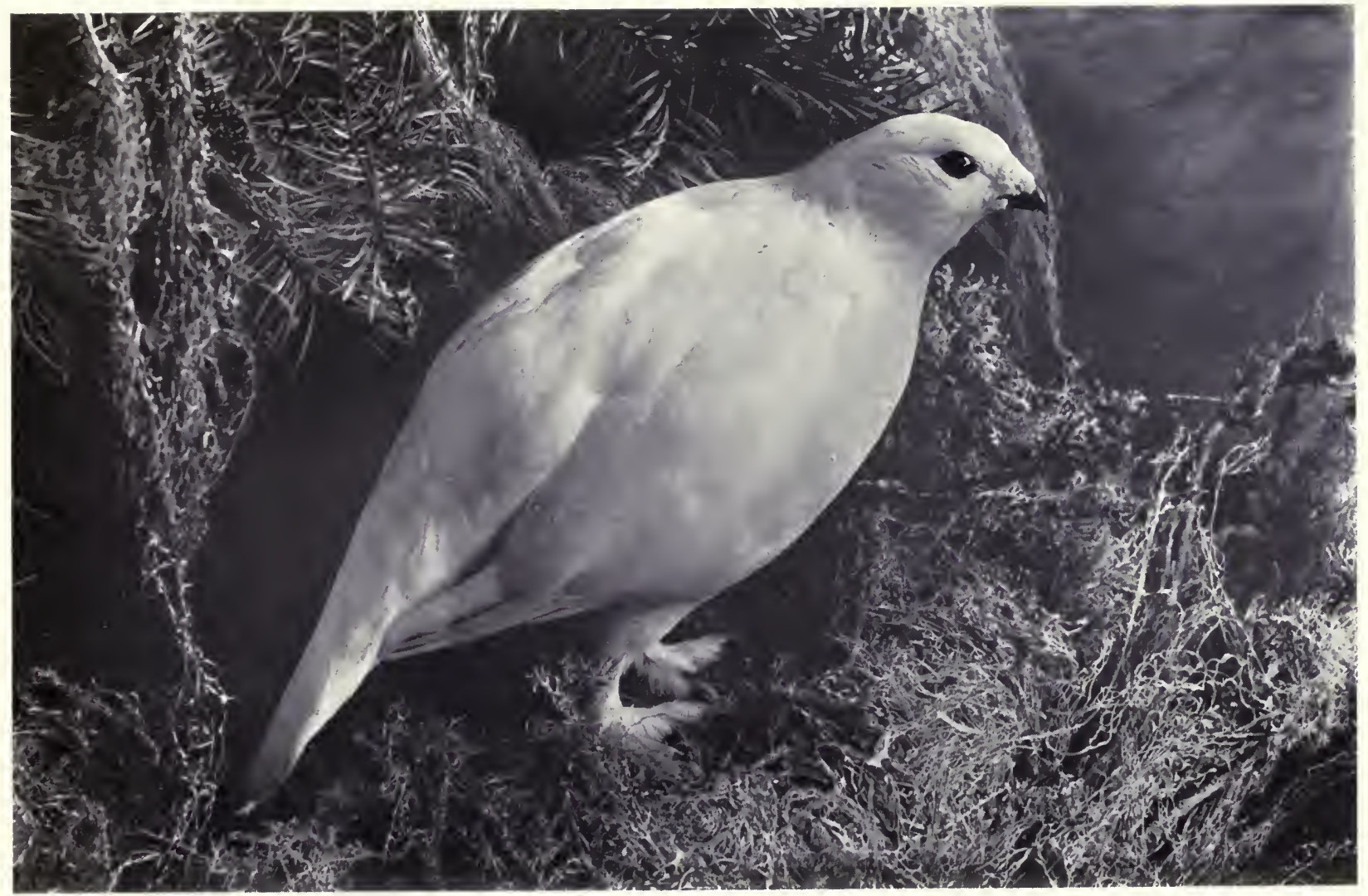





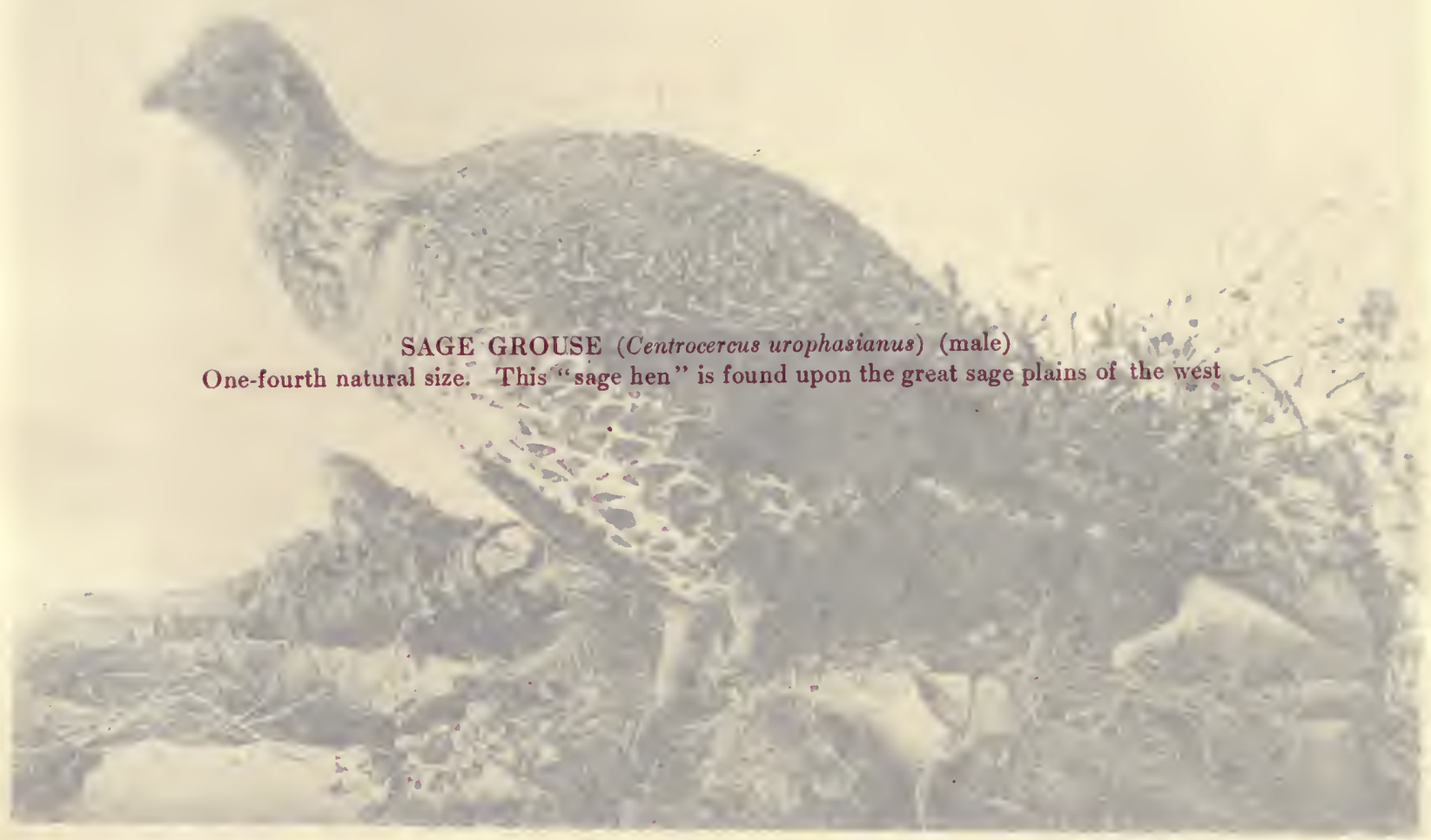


(9lsm) (8แs

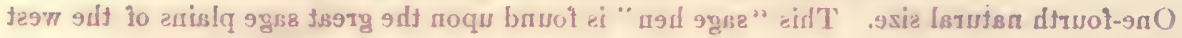




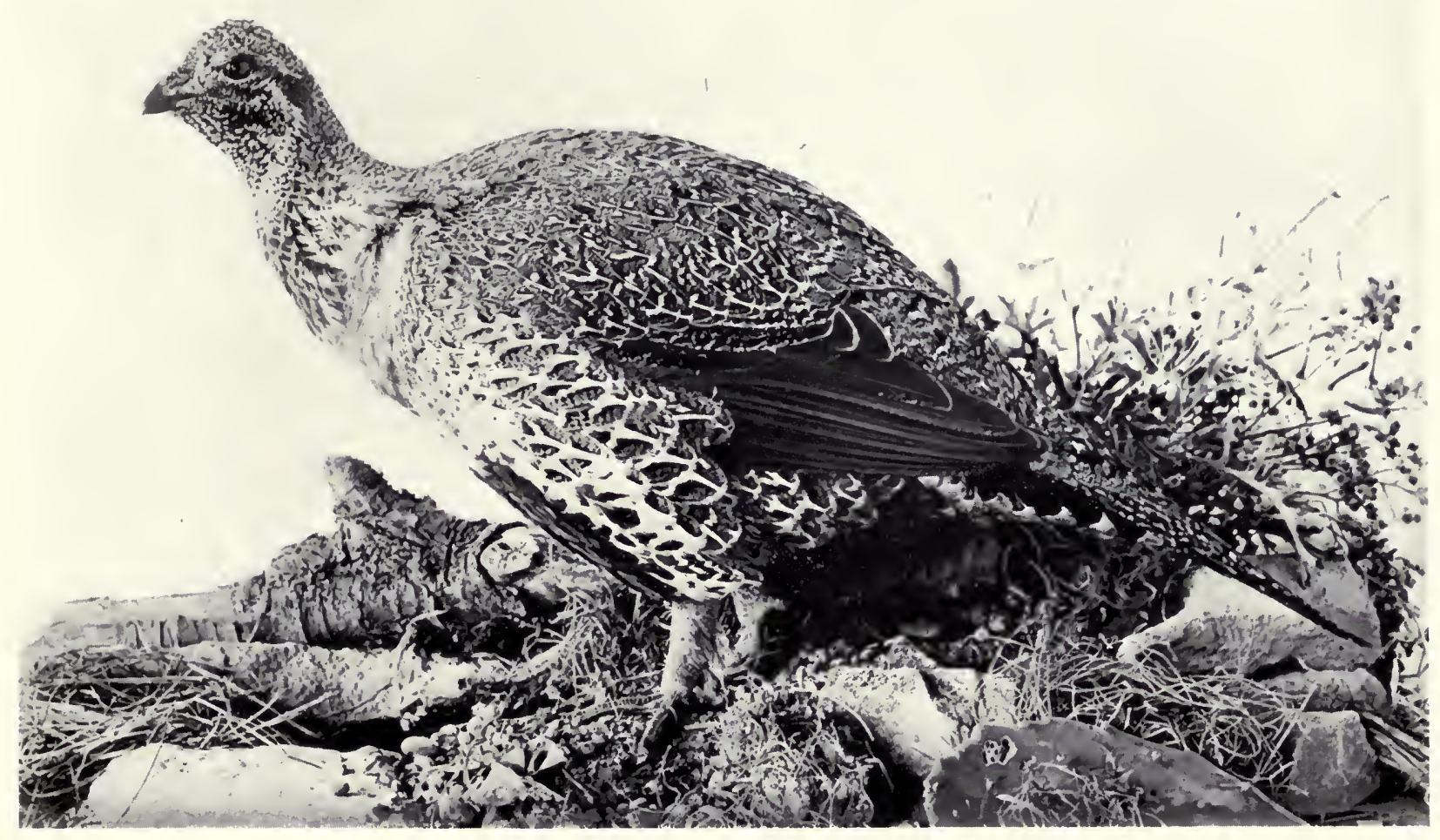




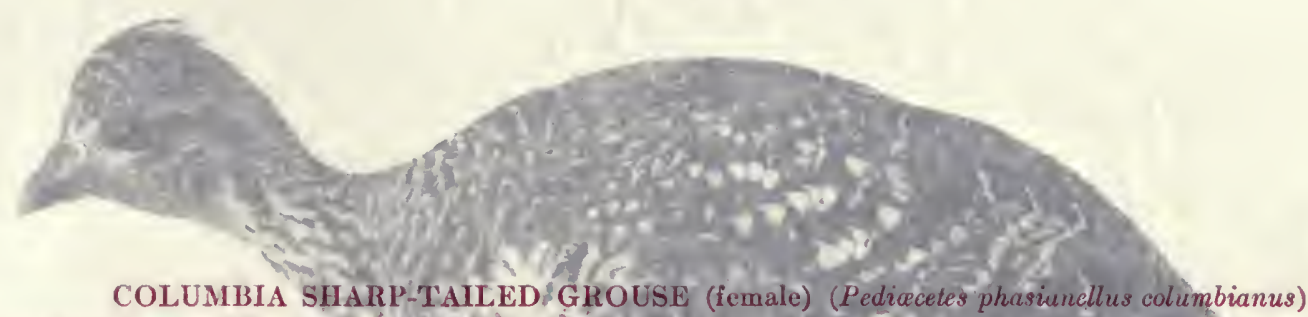

One-third natural size. The Columbia sharp-tailed grouse is the "prairie chicken" sanging west of Montana, from central

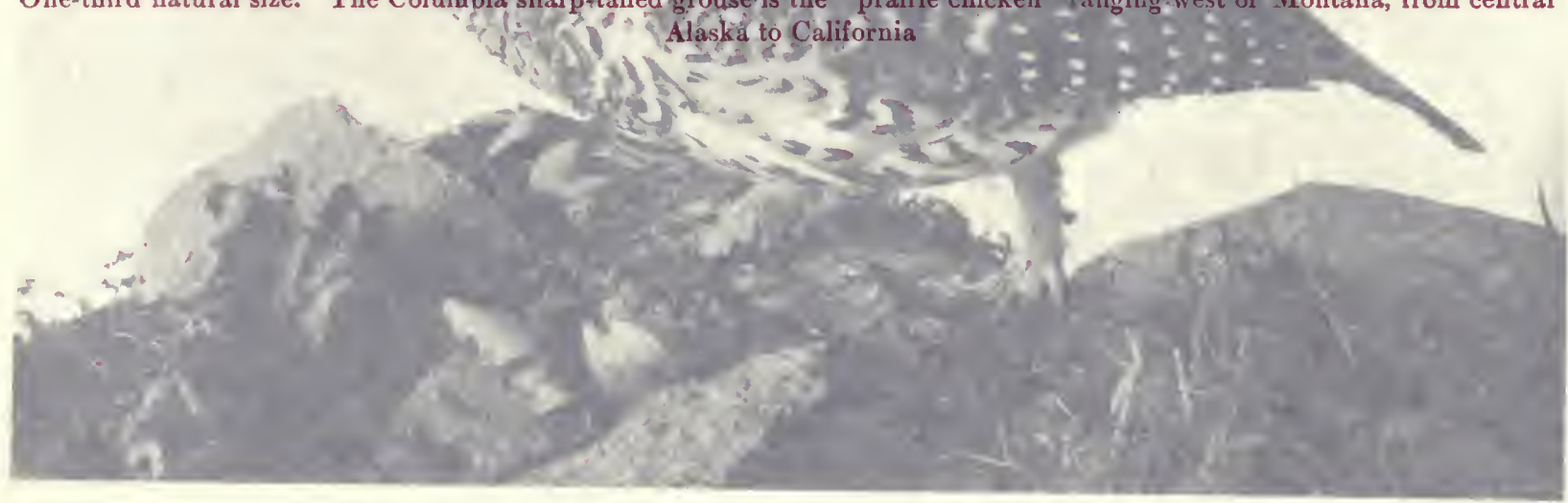




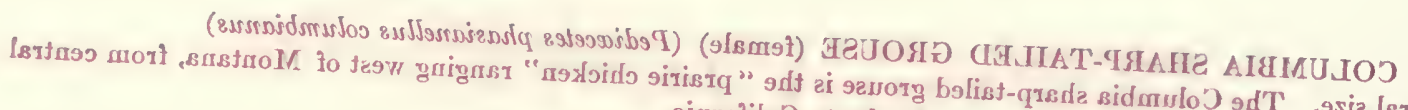
siarotils of steslA 


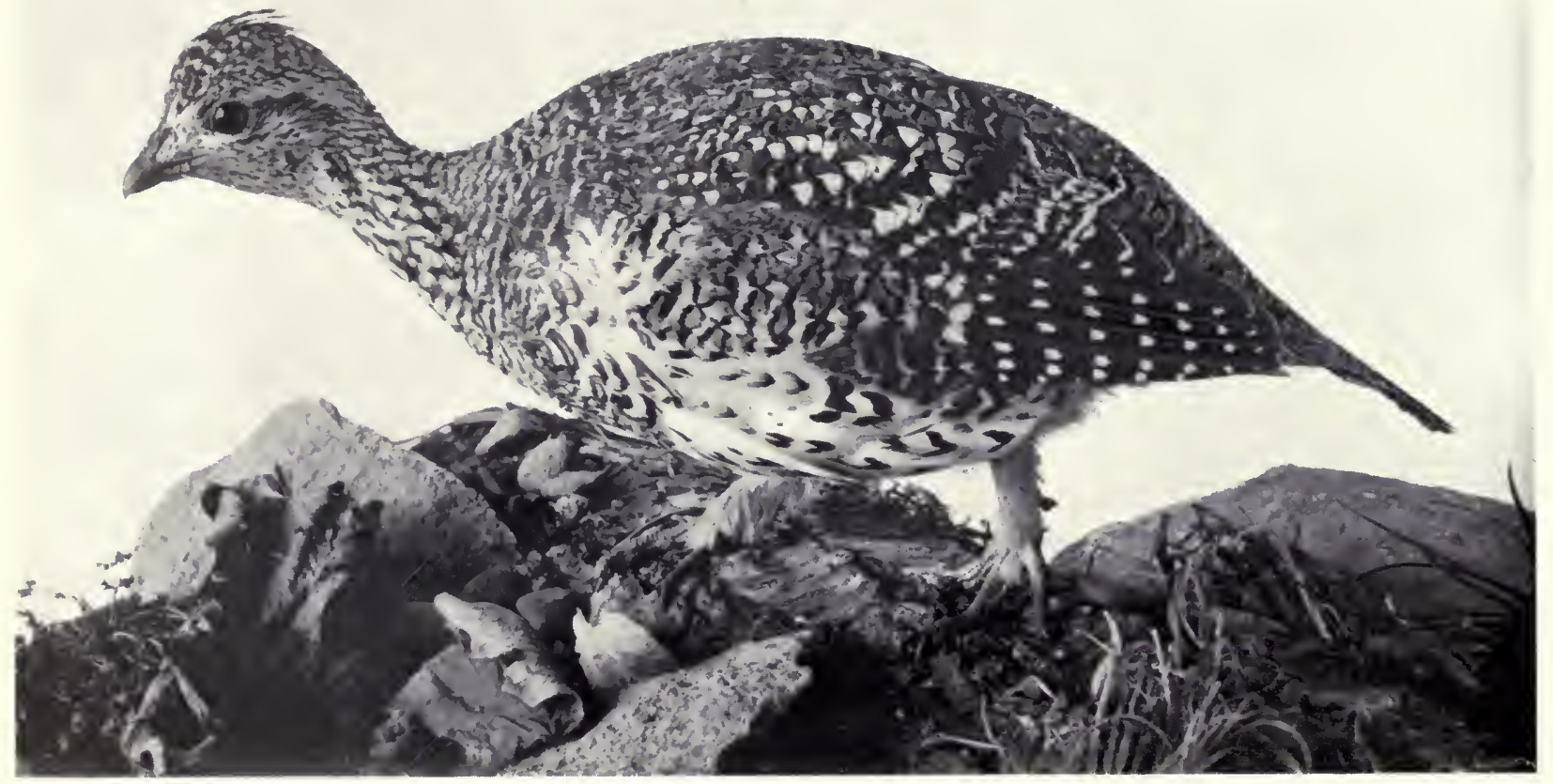




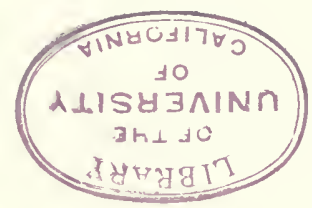




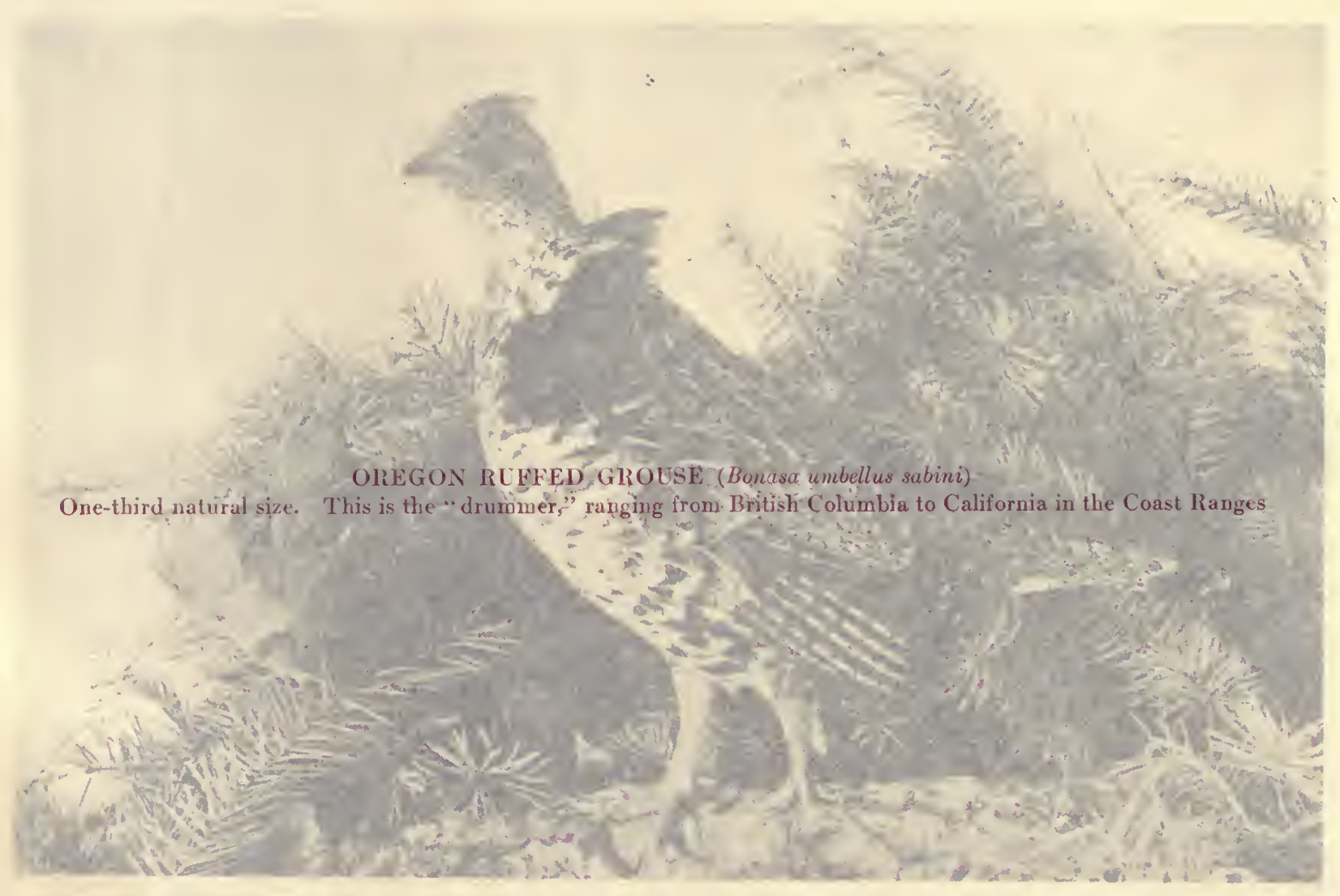




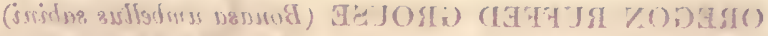

2. 


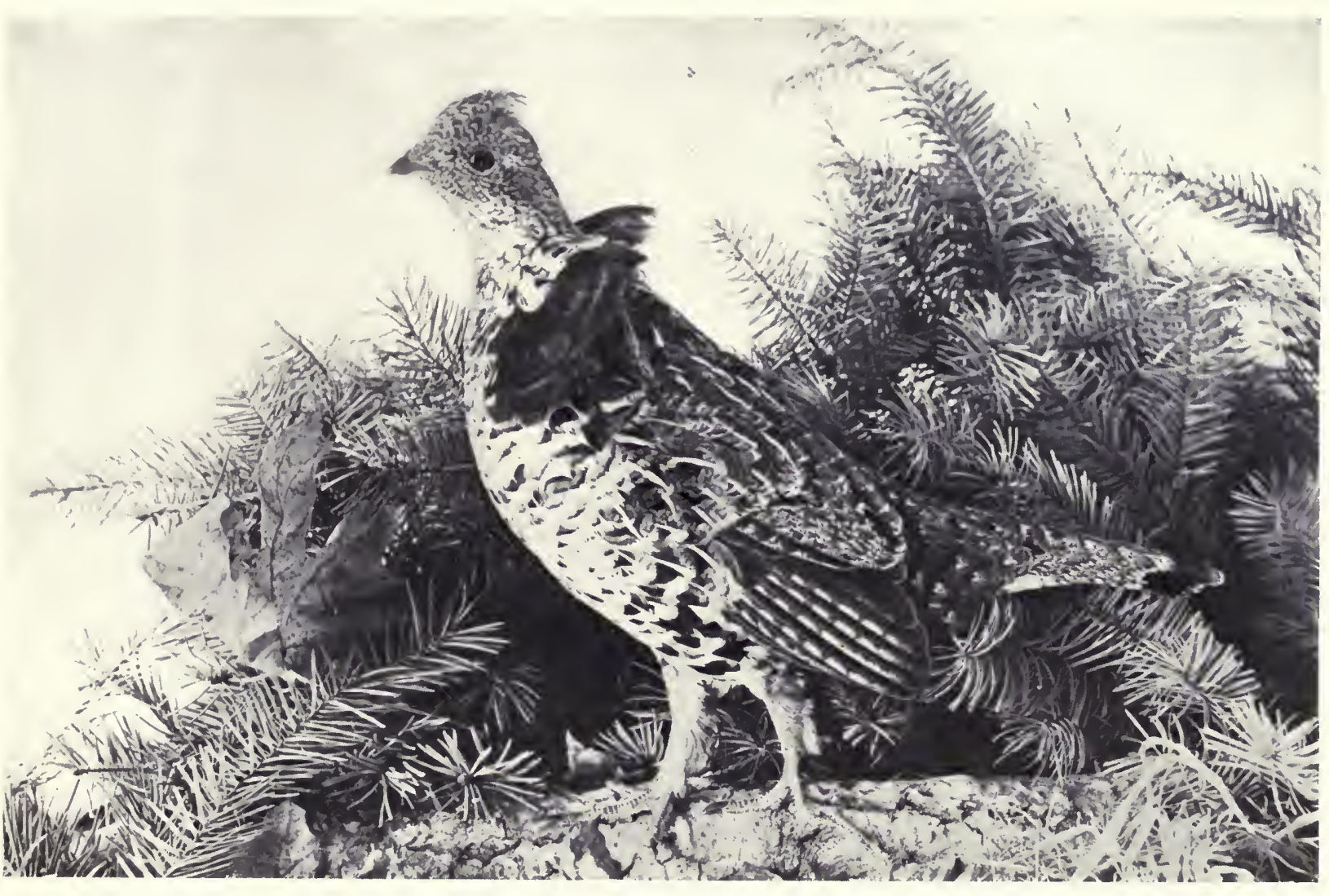




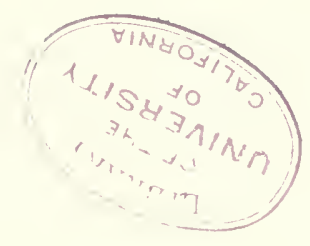




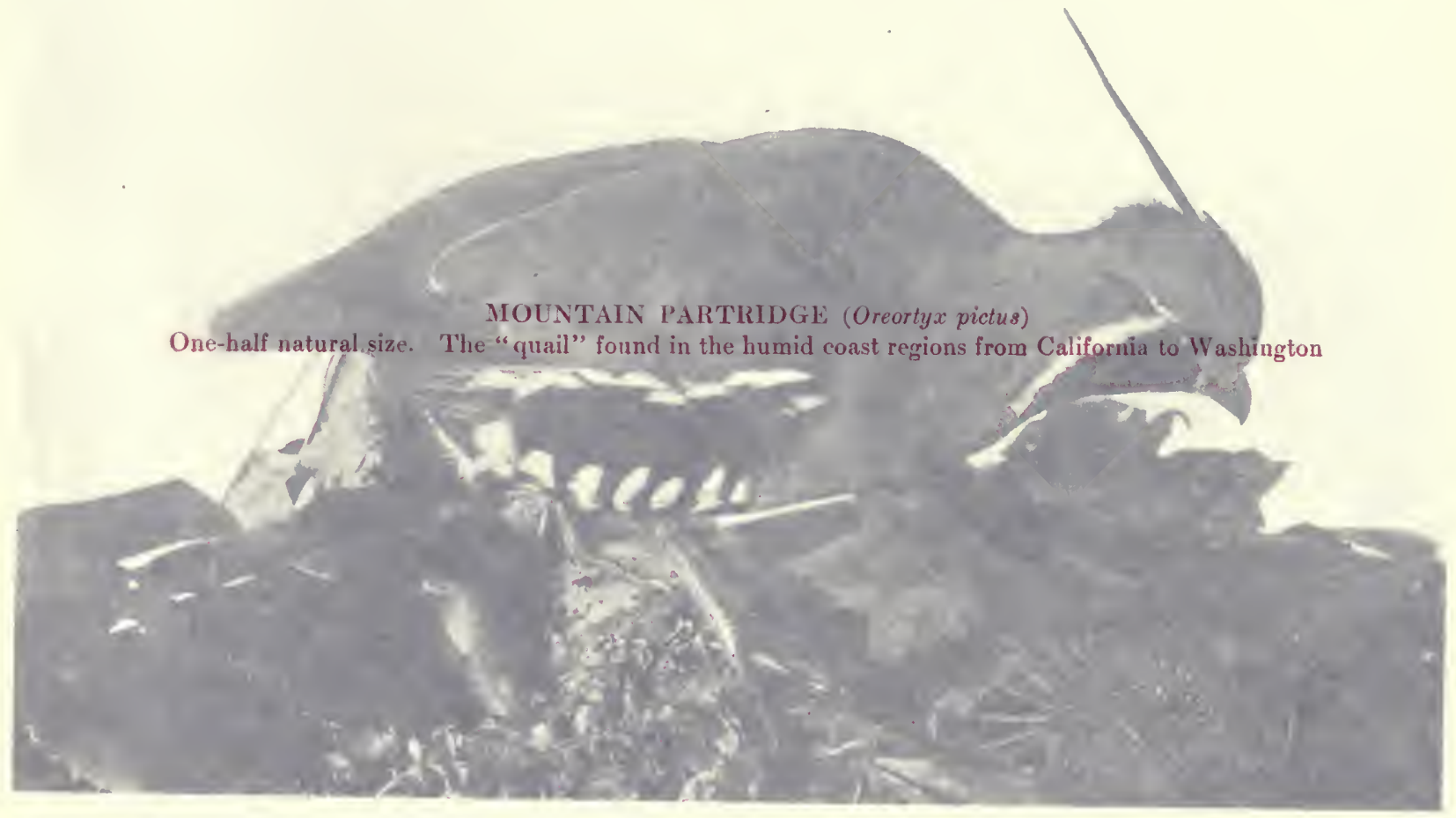




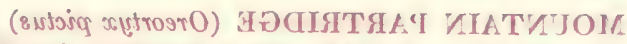

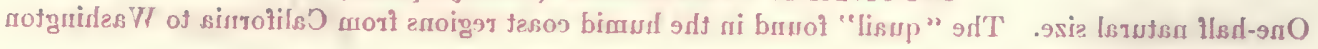




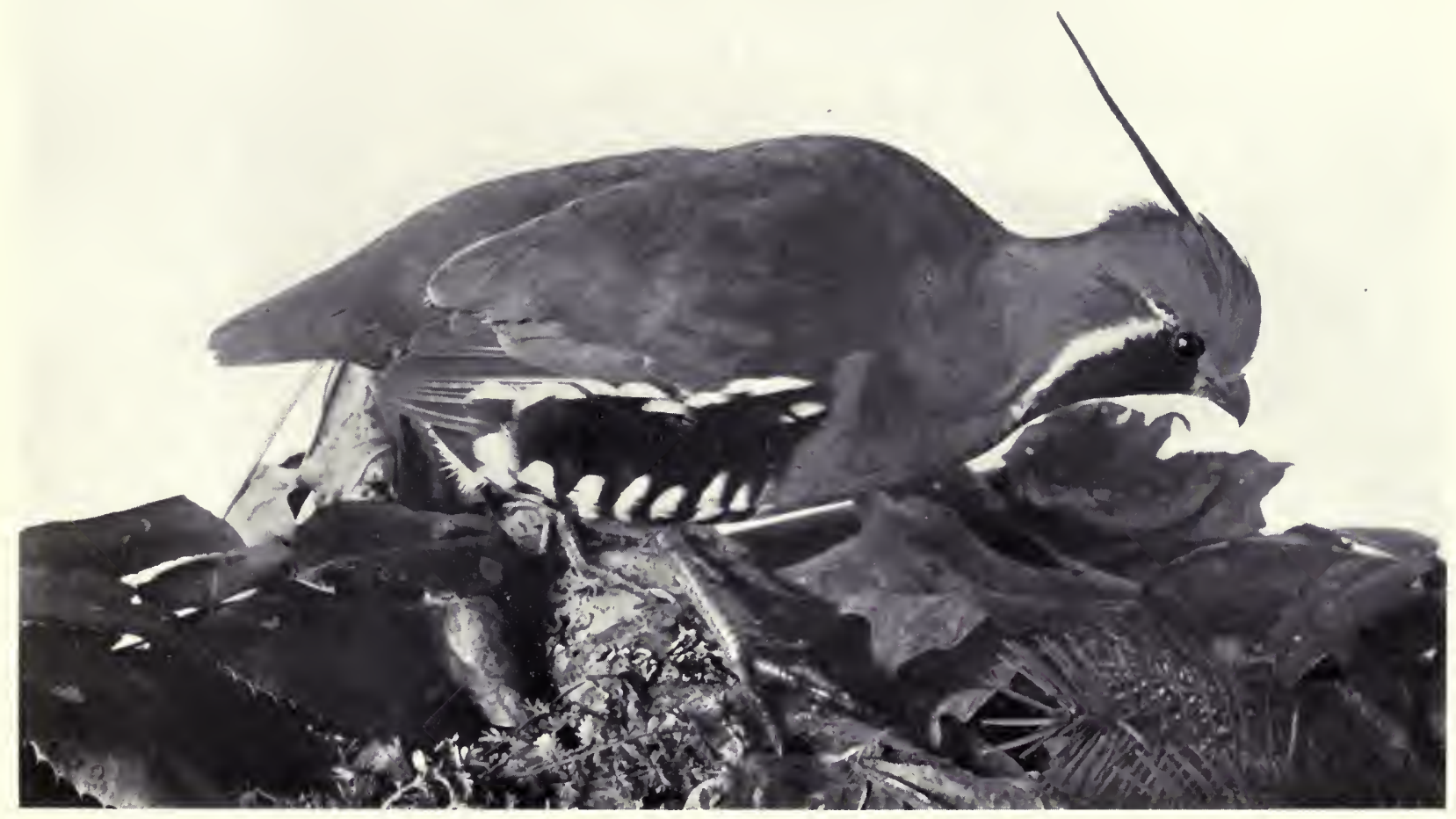




$$
9
$$




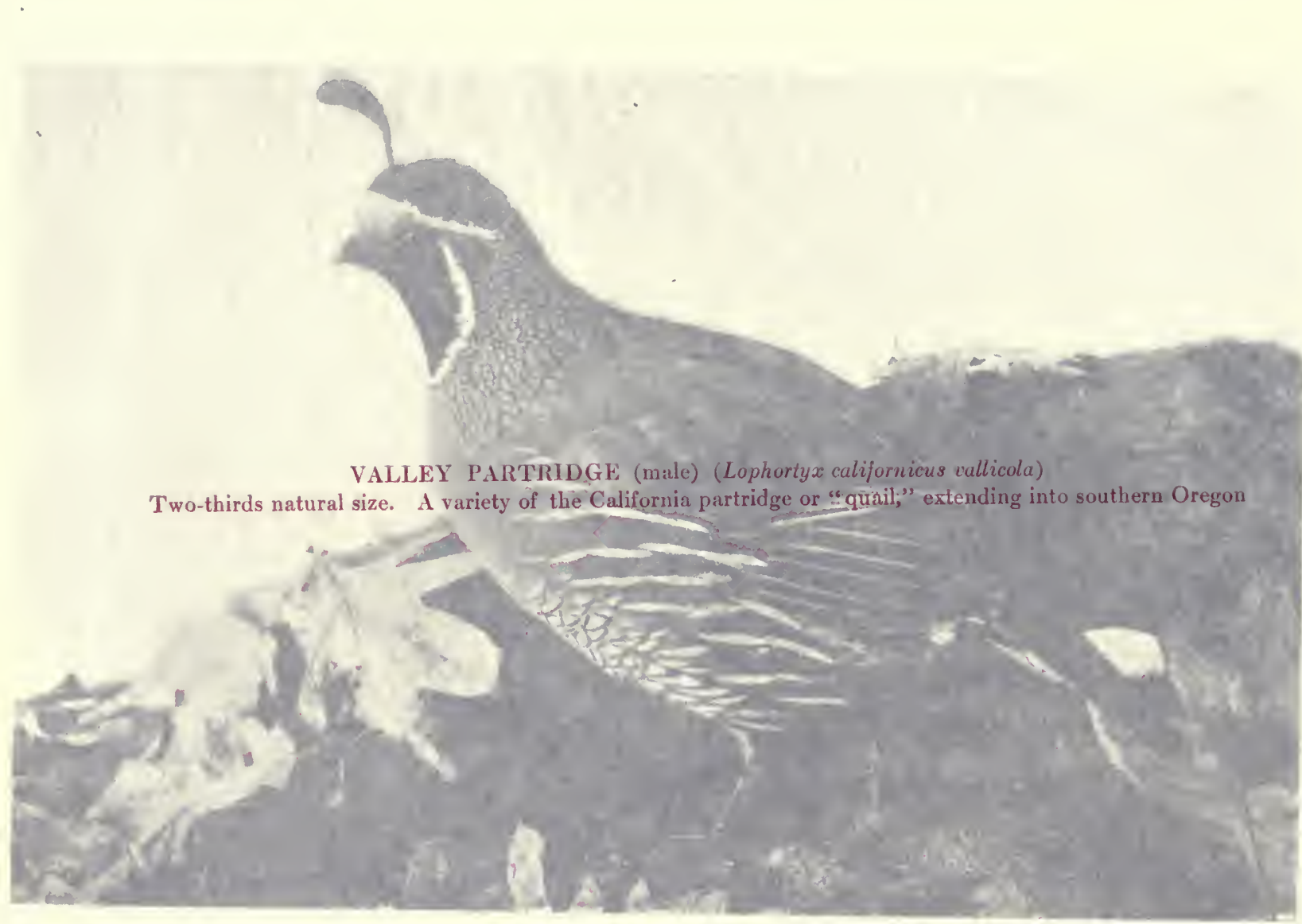




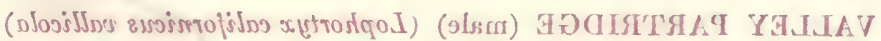

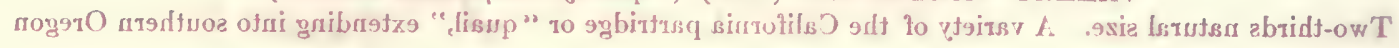




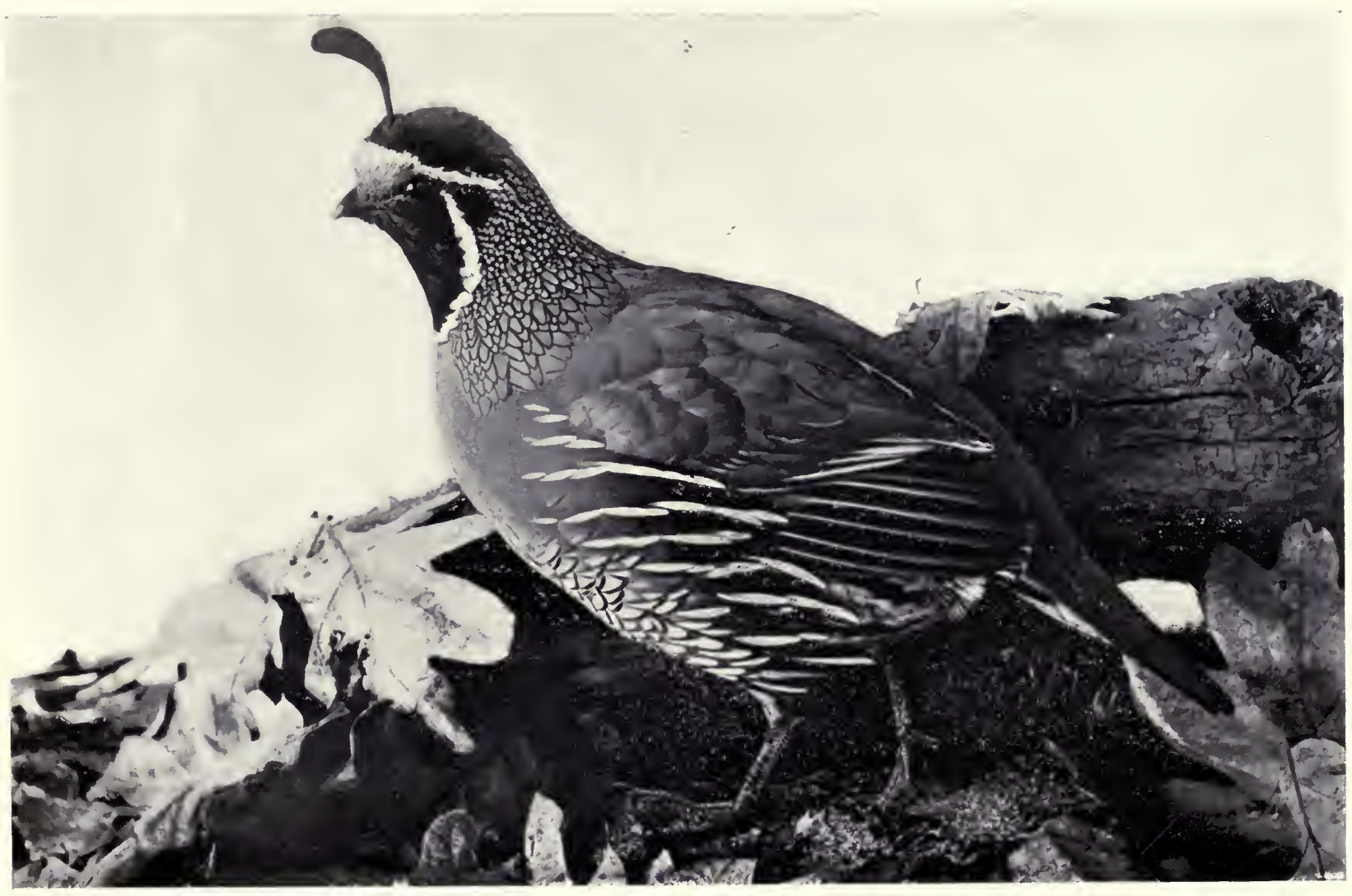




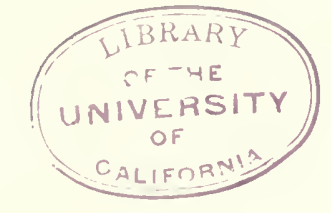




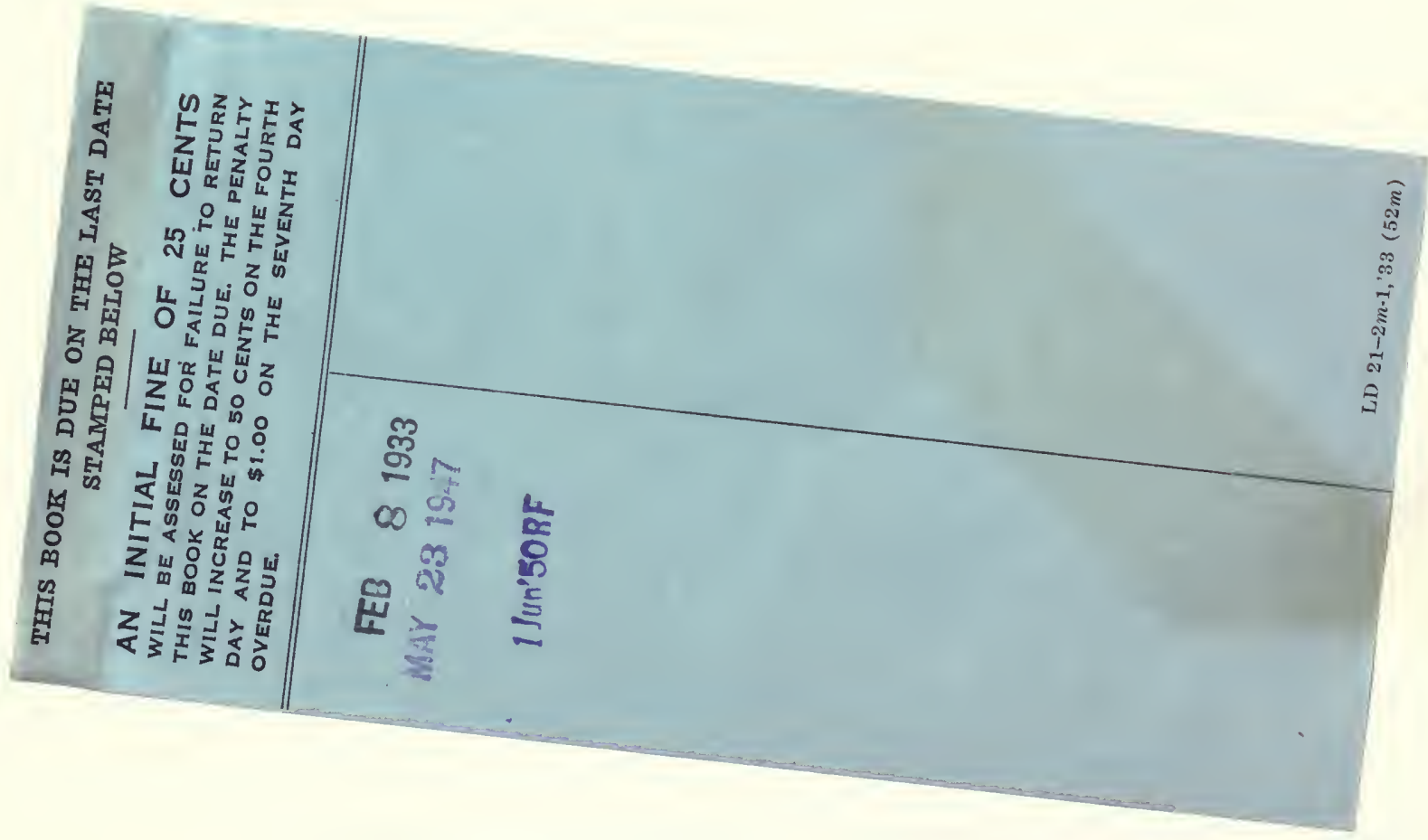




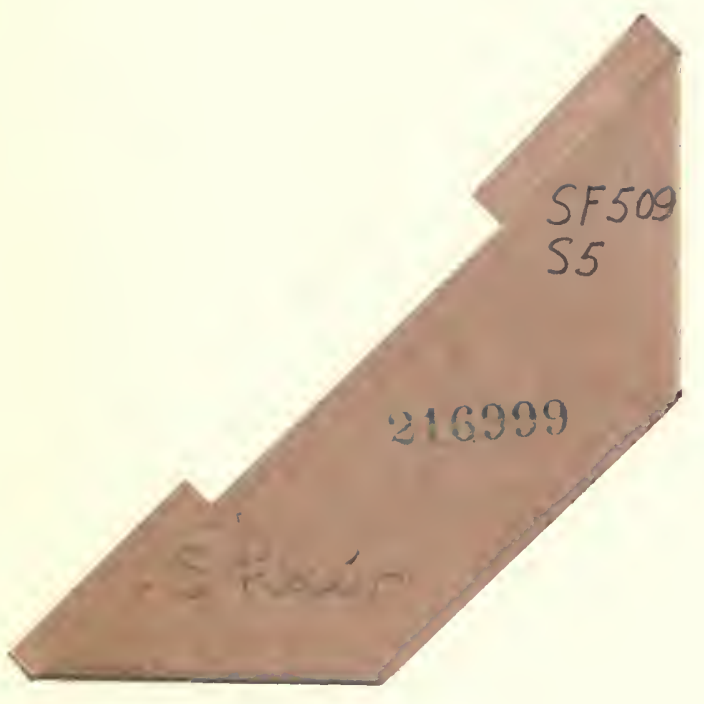


